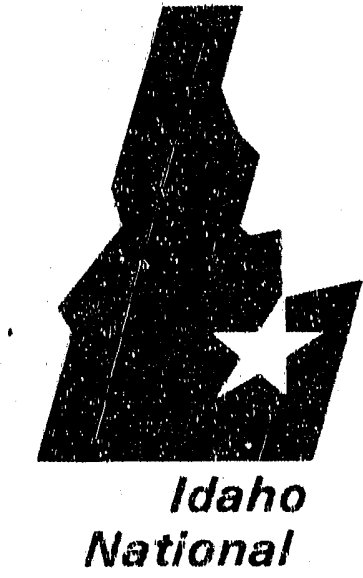

Engineering Laboratory

Managed

by the U.S.

Department

of Energy
EGG-GEO-10159

April 1992
Toxic Vapor Cloud Impacts From Accidental Releases of Anhydrous Ammonia and Nitrogen Dioxide at the ICPP NOx Abatement Facility

Michael L. Abbott

\footnotetext{
$\operatorname{Egrac}_{\text {Iato }}$
}

Work perrotmeg under

DOE Contract

NO DE. ACO7.7610915\% 
This document contains new concepts or the author(s) interpretation of new calculations and/or measurements; accordingly, EG\&G Idaho, Inc. is required by the United States Government to include the following disclaimer:

\section{DISCLAIMER}

This report was prepared as an account of work sponsored by an agency of the United States Govermment. Neither the United States Govemment nor any ageney thereot, nor any of their employees, makes any warranty, express or implied, or assumes any legal liability or responsibility for the accuracy, compieteness, or usefuiness of any information, apparatus, procivet or process disclosed, or reprezents that its use would not infringe privately owned rights. References herbin to any specific corrimercial product, prccess, or service by trace name, trademark. manufacturer, or otherwise, does not necessanly constitute or imply its endorsement, recommendation. or favoring by the United States Govemment or any agency thereot. The views and opinions of authors expressed herein do not necessarity state or reflect those of the United States Govemment or any agency thereot.

$$
\therefore \quad-\cdots
$$$$
\therefore \cdots
$$$$
\therefore-\therefore
$$ 


\title{
TOXIC VAPOR CLOUD IMPACTS FROM ACCIDENTAL RELEASES OF ANHYDROUS AMMONIA AND NITROGEN DIOXIDE AT THE ICPP NOX ABATEMENT FACILITY
}

\author{
Michael L. Abbott
}

Published April 1992

\section{Idaho National Engineering Laboratory \\ EG\&G idaho, Inc. Idaho Falls, Idaho 83415}

\footnotetext{
Prepared for Westinghouse Idaho Nuclear Company and the U. S. Department of Energy Assistant Secretary for Defense Programs Under DOE Field Offlce, Idaho Contract No. DE-AC07-761D01570
} 


\begin{abstract}
This report evaluates potential atmospheric and human health impacts that may result from accidental releases of anhydrous ammonia and nitrogen dioxide at the Idaho Chemical Processing Plant (ICPP) NOx Abatement Facility. Excess process gas releases are evaluated using a traditional Gaussian puff model. Dense two-phase aerosol releases from an 18,000 gallon liquified ammonia storage tank and a 6,000 gallon tanker truck accident are evaluated using the refined vapor dispersion model, SLAB. The SLAB results are also compared to those using the neutral-buoyancy puff model. $A$ SLAB sensitivity analysis is presented which examines various combinations of ambient temperatures and wind speeds in order to determine worst-case downwind air concentrations. The results from the storage tank releases indicated that potentially serious ammonia concentrations (greater than $1000 \mathrm{ppm}$ ) could result at downwind distances ranging from 150 meters (relief valve malfunction) to approximately 3 kilometers (catastrophic tank failure). $T_{\text {. }}$ : tank failure scenario produced concentrations that could be rapidly fatal (greater than $5000 \mathrm{ppm}$ ) out to 1.3 kilometers. Under worst-case meteorological dispersion conditions, recognized exposure limits (IDLH, TLV-STEL) were exceeded for very large distances (greater than 15 kilometers).
\end{abstract}




\section{CONTENTS}

ABSTRACT ........................... i iii

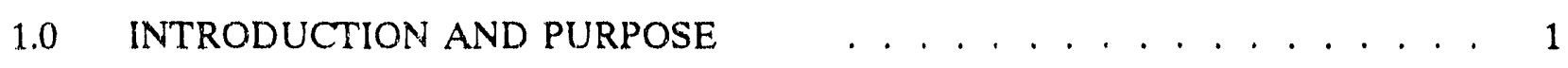

2.0 METHODS ........................... 1

2.1. Identification of Accident Scenarios _. . . . . . . . . . . 1

2.2 Air Dispersion Modeling . . . . . . . . . . . . . 2

2.2.1 Stack Gas Releases . . . . . . . . . . . . . . . . . . . . 3

2.2.1.1 Model Description . . . . . . . . . . . . . . 3

2.2.1.2 Model Parameters . . . . . . . . . . . . 5

2.2.2 Aerosolized $\mathrm{NH}_{3}$ Releases . . . . . . . . . . . . . . . . . . 7

2.2.2.1 Model Description . . . . . . . . . . . . . . 7

2.2.2.2 Model Parameters . . . . . . . . . . . . . . . . . . 8

2.2.2.3 SLAB Meteorological Input Parameters 10

3.0 RESULTS . . . . . . . . . . . . . . . . . . . . . . 12

4.0 REFERENCES ......................... 24

APPENDIX A--SLAB SENSITIVITY RUNS . . . . . . . . . . . . . . . . A-1

FIGURES

1. 15 -min average $\mathrm{NH}_{3}$ concentration $-\mathrm{NH}_{3}$ valve failure . . . . . . . . . . . 12

2. 15 -min average $\mathrm{NH}_{3}$ concentration $-\mathrm{NH}_{3}$ slip ................ 13

3. 15-min average $\mathrm{NO}_{2}$ concentration $-\mathrm{NO}$, process line break ......... 14

4. Near field $\mathrm{NH}_{3}$ concentration - tank relief valve malfunction . . . . . . . . 16

5. Site boundary $\mathrm{NH}_{3}$ concentration - tank relief valve malfunction . . . . . . . . 17 
6. Near field $\mathrm{NH}_{3}$ concentration $-18,000$ gal storage tank rupture . . . . . . . . 19

7. Site boundary $\mathrm{NH}_{3}$ concentration $-18,000$ gal storage tank rupture . . . . . 20

8. Near field $\mathrm{NH}_{3}$ concentration $-6,000$ gal tanker truck accident . . . . . . . . 22

9. Site boundary $\mathrm{NH}_{3}$ concentration $-6,000$ gal tanker truck accident . . . . . 23

A-1 SLAB concentrations for various wind speeds at $-9^{\circ} \mathrm{C}$ temperature $\quad . \quad$. . . A-2

A-2 SLAB concentrations for various wind speeds at $5.6^{\circ} \mathrm{C}$ temperature $\quad .$. . . A-3

A-3 SLAB concentrations for various wind speeds at $20^{\circ} \mathrm{C}$ temperature . . . . . A-4

A-4 SLAB concentrations for various temperatures at a wind speed of $1 \mathrm{~m} / \mathrm{s}$. . . . A-5

A-5 SLAB concentrations for various temperatures at a wind speed of $2 \mathrm{~m} / \mathrm{s}$. . . . A-6

A-6 SLAB concentrations for various temperatures at a wind speed of $3.4 \mathrm{~m} / \mathrm{s}$. . . . A-7

A-7 SLAB concentrations for various temperatures and wind speeds . . . . . . . . A-8

\section{TABLES}

1. Accident scenario source term release parameters . . . . . . . . . . . . . . . 7

2. Temperature-dependent SLAB parameters for 2-phase $\mathrm{NH}_{3}$ releases _. . . . 8 


\section{TOXIC VAPOR CLOUD IMPACTS FROM ACCIDENTAL RELEASES OF ANHYDROUS AMMONIA AND NITROGEN DIOXIDE AT THE ICPP NOX ABATEMENT FACILITY}

\subsection{INTRODUCTION AND PURPOSE}

This report evaluates potential hurnan health impacts resulting from accidental atmospheric release of hazardous chemicals during operation of the proposed NOx Abatement Facility (NAF) at the Idaho Chemical Processing Plant (ICPP). Six potential accidents involving releases of anhydrous ammonia $\left(\mathrm{NH}_{3}\right)$ and nitrogen dioxide $\left(\mathrm{NO}_{2}\right)$ are evaluated and downwind air concentrations are calculated using a Gaussian "Puff" model' and the refined vapor dispersion model, $\mathrm{SLAB}^{2}$. Maximum ground-level concentrations are compared to the chemical's 15-min Short Term Exposure Limit (STEL) established by the American Conference of Governmental Industrial Hygienists (ACGIH) ${ }^{3}$ and human toxicity hazards are discussed.

\subsection{METHODS}

\subsection{Identification of Accident Scenarios}

Six accident scenarios that could occur during operation of the NAF were identified by ICPP project management ${ }^{4,5}$ :

1. $\mathrm{NH}_{2}$ Valve Failure - excess process $\mathrm{NH}_{3}$ gas from a $70 \mathrm{psig}, 400$-ft long, 1 -in diameter underground pipeline is discharged to the 250-ft ICPP main stack.

2. $\mathrm{NH}_{3}$ Slip - excess $\mathrm{NH}_{3}$ gas is released to a cell and is then discharged out the $60-\mathrm{ft}$ NAF stack. Potential release quantities are 10,100 , and $1000 \mathrm{ft}^{3}$. 
3. NO, Process Line Break - a process line containing $\mathrm{NO}_{\mathrm{x}}$ gas at a concentration of $33,000 \mathrm{ppm}$ breaks in a cell. $\mathrm{NO}_{\mathrm{x}}$ is discharged to the NAF 50 -ft stack at rate of 2000 scfm for 5-min. In the stack, it mixes with 25,000 scfm of ventilation air.

4. $\mathrm{NH}_{3}$ Storage Tank Relief Valve Malfunction - A pressure relief valve on one of the 18,000 gallon $\mathrm{NH}_{3}$ tanks malfunctions and releases $\mathrm{NH}_{3}$ to the atmosphere for 30 minutes prior to mitigation. The valve orifice is assumed to be $1-\mathrm{cm}$ in diameter.

5. $\mathrm{NH}_{3}$ Storage Tank Rupture - One of the 18,000 gallon tanks in the $\mathrm{NH}_{3}$ storage area fails catastrophically. The entire contents of the tank are immediately released to the atmosphere.

6. $\mathrm{NH}_{2}$ Tanker Truck Accident - A tanker truck loaded with 6000 gallons of $\mathrm{NH}_{3}$ has a major accident enroute to ICPP. The entire contents of the tanker truck are immediately released to the atmosphere.

\subsection{Air Dispersion Modeling}

Downwind concentrations at ground-level were calculated for a 15 -min averaging time for comparisons to the TLV-STEL (Threshold Limit Value-Short Term Exposure Limit) - a 15-minute time-weighted average exposure which should not be exceeded at any time during a work day ${ }^{3}$. For the larger $\mathrm{NH}_{3}$ releases, concentrations are also compared to the IDLH (Immediately Dangerous to Life and Health) level. The IDLH is the maximum concentration from which, in the event of a respirator failure, one could escape within 30 minutes without experiencing any escape-impairing or irreversible health effects ${ }^{6}$. The 15 -min average concentrations calculated in this analysis will be equal to or conservatively bound a 30 -min average concentration, depending on the release duration and the downwind transport time. For $\mathrm{NH}_{3}$, the STEL and IDLH values are $24 \mathrm{mg} / \mathrm{m}^{3}$ and $350 \mathrm{mg} / \mathrm{m}^{3}$, respectively $\left(20^{\circ} \mathrm{C}\right)$. For $\mathrm{NO}_{2}$, the values are $9.6 \mathrm{mg} / \mathrm{m}^{3}$ and $96 \mathrm{mg} / \mathrm{m}^{3}$. 


\subsubsection{Stack Gas Releases}

2.2.1.1 Model Description. Accident scenarios 1 through 3 involve stack releases of pure or diluted vapors (no liquid droplet aerosol). Simple Gaussian plume or puff models ${ }^{1}$ may be used to treat air dispersion of chemical vapors if the pure vapor density is similar to in (neutrally buoyant) or if a chemical is in a small enough concentration that it behaves as a "trace" gas (like air). The vapor density of $\mathrm{NH}_{3}$ is 0.6 (air = 1); therefore, $\mathrm{NH}_{3}$ gas is lighter than air and the pure vapor will quickly disperse into the atmosphere when released (assuming no aerosol formation). However, the stack gas releases evaluated in this assessment will be rapidly diluted with large quantities of ventilation air prior to release. Under these conditions, the $\mathrm{NH}_{3}$ will likely exhibit neutral buoyancy, and a Gaussian "trace" gas model will provide a conservative estimate of ground-level concentrations. Although pure $\mathrm{NO}_{2}$ gas is heavier than air (vapor density $=1.58$ ), the $\mathrm{NO}_{\mathrm{x}} /$ ventilation air mixture evaluated in this analysis was calculated to have a relative vapor density of 1.23. A gas mixture with a relative vapor density of less than 1.5 may be evaluated using a "trace" gas model".

The $\mathrm{NH}_{3}$ and $\mathrm{NO}_{2}$ releases were estimated to occur over relatively short time intervals (less than the 15-min averaging time) and can therefore be modeled using the integraied form of the Gaussian "puff" equation':

$$
\psi(x, y, 0)=\frac{Q}{\pi \sigma_{y} \sigma_{z} u} \operatorname{EXP}\left[-\left(\frac{h^{2}}{2 \sigma_{z}^{2}}\right)\right]
$$

where

$$
\begin{aligned}
& \Psi(\mathrm{x}, \mathrm{y})=\text { integrated concentration of puff }\left(\mathrm{mg}-\mathrm{s} / \mathrm{m}^{3}\right) \\
& \mathrm{Q}=\text { total mass released }(\mathrm{mg}) \\
& \sigma_{y, z}=\text { standard deviation of the puff in the } \mathrm{y} \text { and } \mathrm{z} \text { directions }(\mathrm{m}) \\
& \mathrm{u}=\text { wind speed }(\mathrm{m} / \mathrm{s}) \\
& \mathrm{h}=\text { height of release }(\mathrm{m})
\end{aligned}
$$


The $\sigma_{y}$ and $\sigma_{z}$ values are taken from $\mathrm{Kunkel}^{8}$ for Pasquill-Gifford (P-G) stability category $\mathrm{F}$ (stable).

Worst-case (generic 95\%) dispersion conditions at ICPP have generally been specified as stability class $\mathrm{F}$ and $2 \mathrm{~m} / \mathrm{s}$ wind ${ }^{9}$. A more conservative $0.5 \mathrm{~m} / \mathrm{s}$ wind speed has been specified for ground-level releases and downwind distances of less than $2 \mathrm{~km}$ to account for building drag effects. For these analyses, a $2 \mathrm{~m} / \mathrm{s}$ wind speed is considered to be a reasonably couservative assumption.

For stack releases, equation (1) is not conservative for near-field receptors (within 0.5 to $2 \mathrm{~km}$, depending on the stack height) because the plume wiil not reach the ground. For ICPP workers, fumigation conditions will generally result in much higher air concentrations. This meteorological phenomenon occurs when the nocturnal temperature inversion at the surface is being broken up by surface heating shortly after sunrise and usually lasts from 60 to 90 minutes. ${ }^{10}$ Fumigation limits vertical dispersion to the area between the ground and the base of the inversion layer. At the INEL, morning mixing heights associated with this inversion layer are estimated to occur at $100-\mathrm{m}$ regardless of the season ${ }^{10}$. To simulate furnigation conditions for ICPP worker exposure, the following equation is used ${ }^{1}$ :

$$
\chi_{F}(x, 0)=\frac{Q}{(2 \pi)^{0.5} u h_{i} \sigma_{y}}
$$

where

$$
\begin{aligned}
& \chi_{F}(x, 0)=\text { concentration at ground-level during fumigation }\left(\mathrm{mg} / \mathrm{m}^{3}\right) \\
& h_{i}=\text { height of the version layer }(\mathrm{m})
\end{aligned}
$$

Although equation (2) is a steady-state plume equation, it may be used to calculate integrated puff concentration when "Q" is in total mass (mg). ${ }^{1}$ A conservative procedure used at the INEL and specified by NRC for nuclear plant accidents ${ }^{11}$ has bcen to set the height of the inversion layer $\left(h_{i}\right)$ equal to the stack height. 
The 15 minute average concentration $\left(\mathrm{C}_{\text {avg }}\right.$ ) was calculated by dividing the integrated puff concentrations in equations (1) and (2) by 900 seconds $\left(t_{\text {avg }}\right)$ :

$$
C_{\text {avg }}\left(m g / m^{3}\right)=\frac{\Psi\left(m g-s / m^{3}\right)}{t_{\text {avg }}(s)}
$$

2.2.1.2 Model Parameters. For the stack releases (accident scenarios 1 through 3), a release mass $(\mathrm{Q}$, in grams) was calculated using the following equations:

$$
\mathbf{Q}=\mathbf{n M W} \text { and } \mathbf{n}=\mathbf{P V} / \mathbf{R T} \text { (ideal gas equation) }
$$

where

$$
\begin{aligned}
& \mathrm{n}=\text { amount of gas (moles) } \\
& \mathrm{MW}=\text { gas molecular weight }(\mathrm{g} / \text { mole }) \\
& \mathrm{P}=\text { gas pressure }(\mathrm{atm}) \\
& \mathrm{V}=\text { gas volume }(\mathrm{L}) \\
& \mathrm{R}=\text { gas constant }\left(0.0821 \mathrm{~L} \text { atm } \text { mole }^{-1}{ }^{\circ} \mathrm{K}^{-1}\right) \\
& \mathrm{T}=\text { gas temperature }\left({ }^{\circ} \mathrm{K}\right)
\end{aligned}
$$

The molecular weights of $\mathrm{NH}_{3}$ and $\mathrm{NO}_{2}$ are $17.03 \mathrm{~g}$ and $46.01 \mathrm{~g}$, respectively. For the stack releases, the $\mathrm{NH}_{3}$ and $\mathrm{NO}_{2}$ vapors are assumed to equilibrate to an ambient stack temperature of $20^{\circ} \mathrm{C}$. In this analysis, $100 \%$ of the $\mathrm{NO}_{\mathrm{x}}$ is assumed to be $\mathrm{NO}_{2}$.

$\mathrm{NH}_{2}$ Valve Failure--The volume and mass of pure $\mathrm{NH}_{3}$ in the pipe was calculated to be $62 \mathrm{~L}$ and $250 \mathrm{~g}$, respectively. Using the ideal gas equation, and assuming the same temperature between the 1 -in line and the stack, the $62 \mathrm{~L}$ of $\mathrm{NH}_{3}$ in the 70 psig line will expand to $350 \mathrm{~L}$ once it is discharged to the stack: 


$$
\begin{aligned}
& V_{s}=P_{i} V_{i} / P_{s} \\
& V_{s}=(5.6 \text { atm })(61.8 \mathrm{~L}) / 1 \text { atm }=350 \mathrm{~L}
\end{aligned}
$$

where $\quad \mathrm{V}_{\mathrm{s}}=\mathrm{NH}_{3}$ volume in stack

$\mathrm{P}_{\mathrm{i}}=\mathrm{NH}_{3}$ line pressure $(70 \mathrm{psig}+12.2$ psia @ $5000 \mathrm{ft})(1 \mathrm{~atm} / 14.7 \mathrm{psi})=5.6 \mathrm{~atm}$

$\mathrm{V}_{\mathrm{i}}=\mathrm{NH}_{3}$ volume in line $(62 \mathrm{~L})$

$\mathrm{P}_{\mathrm{s}}=\mathrm{NH}_{3}$ pressure in stack (assumed $=1 \mathrm{~atm}$ )

For the initial screening calculations, this $\mathrm{NH}_{3}$ volume was conservatively assumed to be released as a single "puff" at the top of the main stack (76.2-m high).

$\mathrm{NH}_{3}$ Slip--For the initial screening calculations, only the bounding $1000 \mathrm{ft}^{3}$ release was evaluated. Assuming this volume is $100 \% \mathrm{NH}_{3}$ vapor at a cell pressure and temperature of $1 \mathrm{~atm}$ and $20^{\circ} \mathrm{C}$, the total mass was calculated to be $2.0 \mathrm{E}+04 \mathrm{~g} \mathrm{NH}_{3}$. For the initial screening calculations, the $\mathrm{NH}_{3}$ was assumed to be released as a single "puff" at the top of the NAF stack $18.3 \mathrm{~m}$ high).

NO $x$ Process Line Break--Using the ideal gas equation, the $3.3 \% \mathrm{NO}_{x}$ gas leak can be shown to be equal to a $\mathrm{NO}_{x}$ volume concentration of $6.3 \mathrm{E}+04 \mathrm{mg} / \mathrm{m}^{3}$ at $20^{\circ} \mathrm{C}$ (the conversion reduces to: $\mathrm{mg} / \mathrm{m}^{3}=\mathrm{MW} / 24.04 \times$ volume fraction $\left.\times 10^{6}\right)$. The total $\mathrm{NO}_{\mathrm{x}} / \mathrm{air}$ mixture released to the NAF stack is $2000 \mathrm{ft}^{3} / \mathrm{min} \times 5 \mathrm{~min}$, or $1.0 \mathrm{E}+04 \mathrm{ft}^{3}\left(280 \mathrm{~m}^{3}\right)$.

The source term parameters for accidents 1 through 3 are summarized in Table 1. 
Table 1. Accident scenario source term release parameters.

\begin{tabular}{|l|l|l|l|l|}
\hline Accident & $\begin{array}{l}\text { Gas } \\
\text { Volume (L) }\end{array}$ & $\begin{array}{l}\text { Gas } \\
\text { Mass }(\mathrm{g})\end{array}$ & $\begin{array}{l}\text { Gas } \\
\text { Conc. }(\%)\end{array}$ & $\begin{array}{l}\text { Release } \\
\text { Height }(\mathrm{m})\end{array}$ \\
\hline $\mathrm{NH}_{3}$ valve failure & $350 \mathrm{~L}$ & 250 & 100 & 76.2 \\
\hline $\mathrm{NH}_{3}$ slip & $2.8 \mathrm{E}+04^{*}$ & $2.0 \mathrm{E}+04$ & 100 & 18.3 \\
\hline $\mathrm{NO}_{\mathrm{x}}$ line break & $2.8 \mathrm{E}+05^{\mathrm{b}}$ & $1.8 \mathrm{E}+04$ & 3.3 & 18.3 \\
\hline
\end{tabular}

a. For initial screening calculations, only bounding release $1000 \mathrm{ft}^{3}$ ) evaluated.

b. $\mathrm{NO}_{2}$ and air mix at $20^{\circ} \mathrm{C}$.

\subsubsection{Aerosolized $\mathrm{NH}_{3}$ Releases}

2.2.2.1 Model Description. Accident scenarios 4 through 6 involve releases of d pressurized liquified gas $\left(\mathrm{NH}_{3}\right)$ with a boiling point $\left(-33^{\circ} \mathrm{C}\right)$ that is less than ambient temperatures. Under these conditions, a 2-phase aerosol cloud composed of $\mathrm{NH}_{3}$ gas and suspended liquid $\mathrm{NH}_{3}$ droplets will form ${ }^{12}$. The resulting cloud will remain very cold during downwind transport as the latent heat of vaporization is transferred from the surrounding air to the $\mathrm{NH}_{3}$ droplets. This will result in initial dense gas behavior (gravity slumping) which cannot be simulated using a Gaussian "trace" gas model.

The SLAB ${ }^{2}$ model is one of several refined air toxics dispersion models ${ }^{12}$ currently available that provides a more detailed treatment of the physical, chemical, and thermodynamic processes that may influence dispersion of chemical vapor clouds. SLAB simulates dispersion of denser-than-air gases, the thermodynamics of two-phase vapor-droplet formation and evaporation, the heating of cold clouds (e.g. $\mathrm{NH}_{3}$ ) at the ground surface, and includes lofting of the cloud if it becomes lighter-than-air. The model uses averaged torms of the conservation equations for mass, momentum, energy, and species to calculate spatiallyaveraged and time-averaged cloud properties for two different dispersion modes: steady-state plume and transient puff. 
2.2.2.2 Model Parameters. The downwind dispersion of $\mathrm{NH}_{3}$ calculated in SLAB is dependent upon chemical storage temperature and ambient air temperature, in addition to meteorological factors (stability class, wind speed). SLAB input parameters were therefore calculated for the lowest $\left(-9^{\circ} \mathrm{C}\right.$, January) and the highest $\left(20^{\circ} \mathrm{C}\right.$, July) average monthly temperatures a. the INEL. ${ }^{10}$ Temperature-dependent release parameters include (Table 2):

- Tank storage pressure $\left(P_{s}\right)$

- Initial liquid mass fraction (droplets) (CMEDO)

- Initial two-phase (vapor/droplet) cloud density $\left(\rho_{m}\right)$

Table 2. Temperature-dependent SLAB parameters calculated for 2-phase (vapor/droplet) releases of pressurized liquified $\mathrm{NH}_{3}$.

\begin{tabular}{|l|c|c|c|c|}
\hline Month & Temp $\left({ }^{\circ} \mathrm{C}\right)^{*}$ & $\mathbf{P}_{\text {si }}(\mathrm{atm})$ & $\mathrm{CMEDO}^{6}$ & $\mathbf{P}_{\mathrm{m}}\left(\mathrm{kg} / \mathrm{m}^{3}\right)$ \\
\hline January & -9 & 2.9 & 0.924 & 11.22 \\
\hline July & 20 & 8.2 & 0.833 & 5.18 \\
\hline
\end{tabular}

a. INEL monthily average ${ }^{10}$

b. Mass fraction in the gas phase $(F)=1 .-$ CMEDO.

Tank storage pressures $\left(P_{s t}\right)$ were taken from the vapor pressure vs. temperature curve for $\mathrm{NH}_{3}$ given in Matheson. ${ }^{13}$ The initial liquid mass fraction (CMEDO) and the mixture (vapor/droplet cloud) density $\left(\rho_{\mathrm{m}}\right.$, in $\left.\mathrm{kg} / \mathrm{m}^{3}\right)$ are given by: ${ }^{2}$

$$
C M E D O=1-c_{p} \frac{\left(T_{s}-T_{b}\right)}{L}
$$

and 


$$
\rho_{m}=\frac{1}{(1-C M E D O) / \rho_{y}+(C M E D O) / \rho_{L}}
$$

where

$c_{\mathrm{p}}=$ Liquid heat capacity at constant pressure $\left(4294 \mathrm{~J} /\left(\mathrm{kg}-{ }^{\circ} \mathrm{K}\right)\right.$

$\mathrm{T}_{\mathrm{s}}=$ Temperature of source material $\left({ }^{\circ} \mathrm{K}\right)$

$\mathrm{T}_{\mathrm{b}}=$ Boiling point temperature of source material $\left(239.72^{\circ} \mathrm{K}\right)$

$\mathrm{L}=$ Latent heat of vaporization $(1370840 \mathrm{~J} / \mathrm{kg})$

$\rho_{\mathrm{v}}=$ Vapor density at the boiling point $\left(0.87 \mathrm{~kg} / \mathrm{m}^{3}\right)$

$\rho_{\mathrm{L}}=$ Liquid density $\left(682.0 \mathrm{~kg} / \mathrm{m}^{3}\right)$

The values for the parameters listed above are taken from the SLAB User's Guide for anhydrous am nonia. The value for $\rho_{v}\left(0.87 \mathrm{~kg} / \mathrm{m}^{3}\right)$ was calculated using: ${ }^{2}$

$$
\rho_{v}=\frac{(M W)\left(P_{a}\right)}{\left(R_{c}\right)\left(T_{b}\right)}
$$

where

$$
\begin{aligned}
& \mathrm{MW}=\text { Molecular weight of } \mathrm{NH}_{3}(0.01703 \mathrm{~kg}) \\
& \mathrm{P}_{\mathrm{a}}=\text { Ambient atmospheric pressure }\left(101325 \mathrm{~N} / \mathrm{m}^{2}\right) \\
& \mathrm{R}_{\mathrm{c}}=\text { Gas constant }\left(8.31431 \mathrm{~J} /\left(\text { mole }-{ }^{\circ} \mathrm{K}\right)\right. \\
& \mathrm{T}_{\mathrm{b}}=\text { Boiling point temperature of } \mathrm{NH}_{3}
\end{aligned}
$$

Storage Tank Relief Valve Failure--This release was modeled as a "vertical jet" source type in SLAB. The $\mathrm{NH}_{3}$ mass release rate from a $1-\mathrm{cm}$ diameter $\left(0.785 \mathrm{~cm}^{2}\right)$ valve orifice was calculated using the equation for continuous relief valve discharges (two-phase flow) given in EPA-450/4-88-009: ${ }^{14}$

$$
q_{m}=0.76 \mathrm{~A} \sqrt{P_{m} P_{s}}
$$


where

$$
\begin{aligned}
q_{m} & =\text { total discharge rate for the liquid/vapor mixture }(\mathrm{g} / \mathrm{s}) \\
\mathrm{A} & =\text { release area }\left(\mathrm{cm}^{2}\right) \\
\rho_{\mathrm{m}} & =\text { mixture (vapor/droplet aerosol) d } 2 \text { nsit } \mathrm{y}^{\prime}\left(\mathrm{g} / \mathrm{cm}^{3}\right) \\
\mathrm{P}_{\mathrm{st}} & =\text { tank storage pressure }\left(\text { dynes } / \mathrm{cm}^{2}\right)
\end{aligned}
$$

Using the values for $\rho_{m}$ and $P_{s t}$ listed in Table 2, the January and July release rates were calculated to be $108 \mathrm{~g} / \mathrm{s}$ and $124 \mathrm{~g} / \mathrm{s}$, respectively. Dividing by the aerosol densities $\left(\rho_{\mathrm{m}}\right)$, these mass release rates correspond to aerosol volume release rates of $9.6 \mathrm{E}-03 \mathrm{~m}^{3} / \mathrm{s}(20.4$ $\mathrm{ft}^{3} / \mathrm{min}$ ) during January and $2.4 \mathrm{E}-02 . \mathrm{m}^{3} / \mathrm{s}\left(50.7 \mathrm{ft}^{3} / \mathrm{min}\right)$ during July.

$\mathrm{NH}_{3}$ Storage Tank Rupurre--'This release was modeled as an "instantaneous" source type in SLAB. The total mass of one 18,000 gallon tank was calculated to be 44,230 $\mathrm{kg}$ using a conservative $\mathrm{NH}_{3}$ liquid density of $40.43 \mathrm{lb} / \mathrm{ft}^{3}\left(20^{\circ} \mathrm{F}\right)^{\mathrm{xx}}$. The initial volume of the 2-phase cloud after expansion to 1 atm was calculated by dividing the release mass by the 2phase mixture density $\left(\rho_{m}\right.$, Table 2$)$. For the January $\left(-9^{\circ} \mathrm{C}\right)$ release, the initial volume was calculated to be $3940 \mathrm{~m}^{3}$. For the July $\left(20^{\circ} \mathrm{C}\right)$ release, the initial volume was calculated to be $8540 \mathrm{~m}^{3}$. The release height was assumed to be $4-\mathrm{m}$, based on conceptual design drawings.

$\mathrm{NH}_{3}$ Tanker Truck Accident--This release was also modeled as an "instant neous" source type in SLAB. The total mass of the 6,000 gallon tanker truck was calculated to be $14,740 \mathrm{~kg}$. The initial volume of the 2 -phase cloud af . expansion to $1 \mathrm{~atm}$ was calculated by dividing the release mass by the 2-phase mixture density ( $\rho_{\mathrm{m}}$, Table 2$)$. For the January $\left(-9^{\circ} \mathrm{C}\right)$ release, the initir? yolume was calculated to be $1310 \mathrm{~m}^{3}$. For the July $\left(20^{\circ} \mathrm{C}\right)$ release, the initial volume was calculated to be $2850 \mathrm{~m}^{3}$. The release height was assumed to be $2-\mathrm{m}$.

\subsubsection{SLAB Meteorological Input Parameters. SLAB runs were made using several} combinations of ambient temperatures and wind speeds in order to determine worst-case (highest) potential downwind air concentrations (Appendix A). In contrast to traditicnal Gaussian models, higher wind speeds resulted in the higher site boundary concentrations. 
Lower wind speeds allowed more time for the aerosol cloud to completely vaporize, resulting in lofting of the cloud at shorter downwind distances. Once the cloud begins to loft, groundlevel air concentrations decrease rapidly (Appendix A). Likewise, higher ambient temperatures increased the rate of aerosol vaporization which also resulted in lofting of the cloud at shorter distances. Based on these observations, finai SLAB runs were made using the following values for temperature and wind speed:

\begin{tabular}{lll} 
Accident & Temperature $\left({ }^{\circ} \mathrm{C}\right)$ & Wind Speed (m/s) \\
\cline { 2 - 3 } Tank Rupture (Instant) & -9 (Jan) & $1,2,4.2$ \\
Truck Accident (Instant) & -9 (Jan) & $2,4.2$ \\
Reiief Valve (Vertical Jet) & -9 (Jan), 20 (July) & $2,4.2$
\end{tabular}

The wind speeds chosen represent:

- $1 \mathrm{~m} / \mathrm{s}$ : the lowest practical value that should be used in Gaussian moduls ${ }^{15}$

- $2 \mathrm{~m} / \mathrm{s}$ : a generic worst-case value for site-boundary dispersion at the INEL

- $4.2 \mathrm{~m} / \mathrm{s}$ : the highest monthly average wind speed at the INEL (Aprii) ${ }^{10}$

Other meteorological input parameters used in the SLAB runs are:

- $\quad$ Stability Class: F (stable)

- $\quad$ Surface roughness (ZO): $0.03 \mathrm{~m}$ (level desert)

- $\quad$ Relative humidity: 70\% (February) 


\subsection{RESULTS}

Ground level 15-min concentrations as a function of distance are shown in Figures 1 through 9. Inhalation health effects are taken from reference [16]. The results are summarized below.

$\mathrm{NH}_{3}$ Valve Break. The maximum 15-min concentration at ground-level was calculated to be $0.15 \mathrm{mg} / \mathrm{m}^{3}$ at $100-\mathrm{m}$ distance from the main stack. This is well below the TLV-STEL limit $\left(24 \mathrm{mg} / \mathrm{m}^{3}\right)$ and the lowest level at which minimal irritation effects has been observed $\left(3.5 \mathrm{mg} / \mathrm{m}^{3}\right.$ or $\left.5 \mathrm{ppm}\right)$.

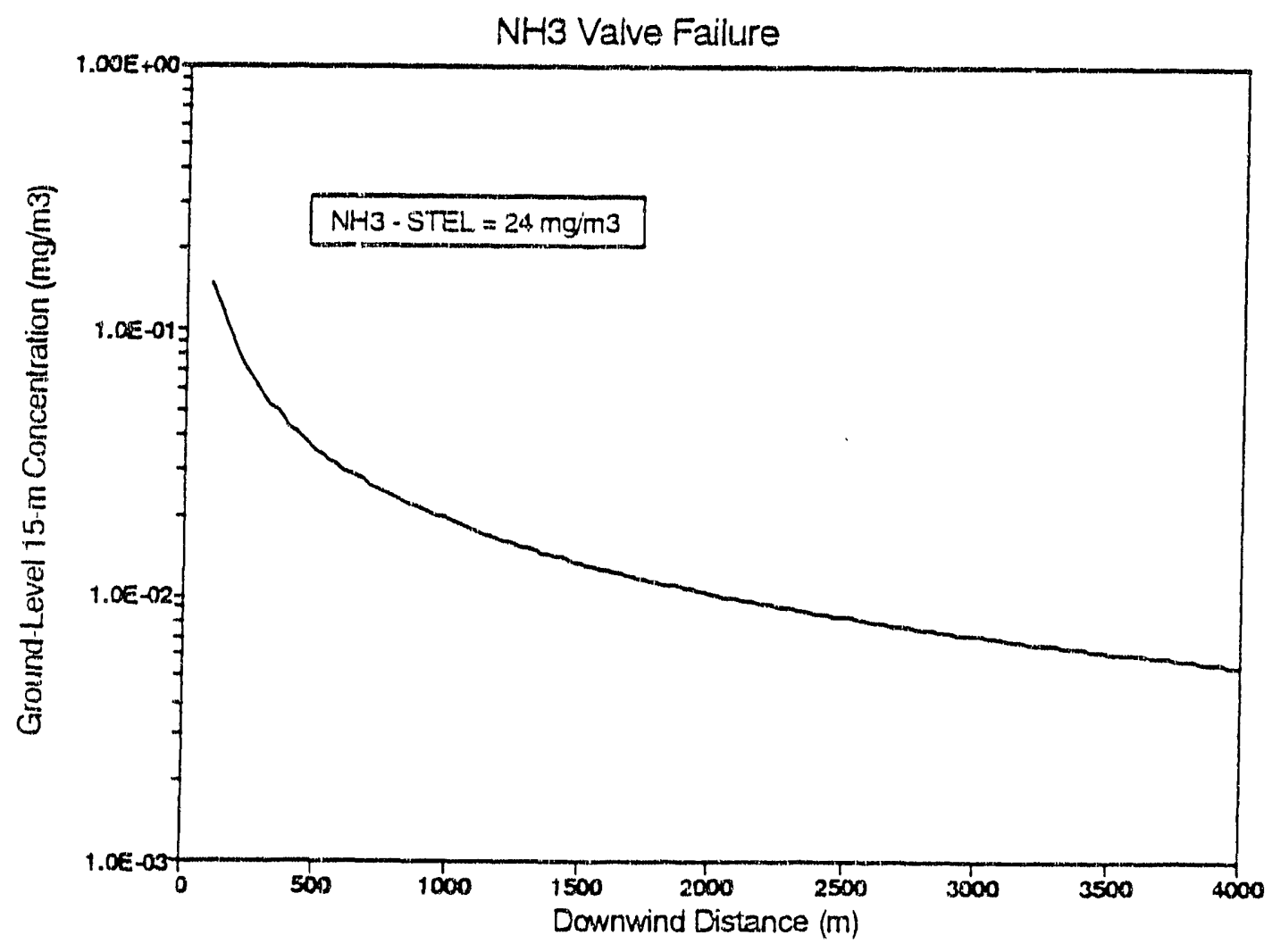

Figure 1. 15-min average $\mathrm{NH}_{3}$ concentrations at ground-level resulting from a valve break and release of $350 \mathrm{~L}_{\text {of }} \mathrm{NH}_{3}$ gas to the ICPP main stack. 
$1000-\mathrm{ft}^{3} \mathrm{NH}_{3}$ Slip. The maximum 15-min concentration at ground-level occurred under fumigation conditions and was calculated to be $51 \mathrm{mg} / \mathrm{m}^{3}(36 \mathrm{ppm})$ at $100-\mathrm{m}$ distance from the NAF stack. At $250 \mathrm{~m}$ from the stack, the concentration fell below the STEL limit $\left(24 \mathrm{mg} / \mathrm{m}^{3}\right)$. Acute exposures in the concentration range from $9-50 \mathrm{ppm}$ have been observed to cause nasal dryness, olfactory fatigue, and moderate irritation. Downwind concentrations resulting from $\mathrm{NH}_{3}$ releases from $100 \mathrm{ft}^{3}$ and $10 \mathrm{ft}^{3}$ can be determined by dividing the results in Figure 2 by 10 and 100 , respectively.

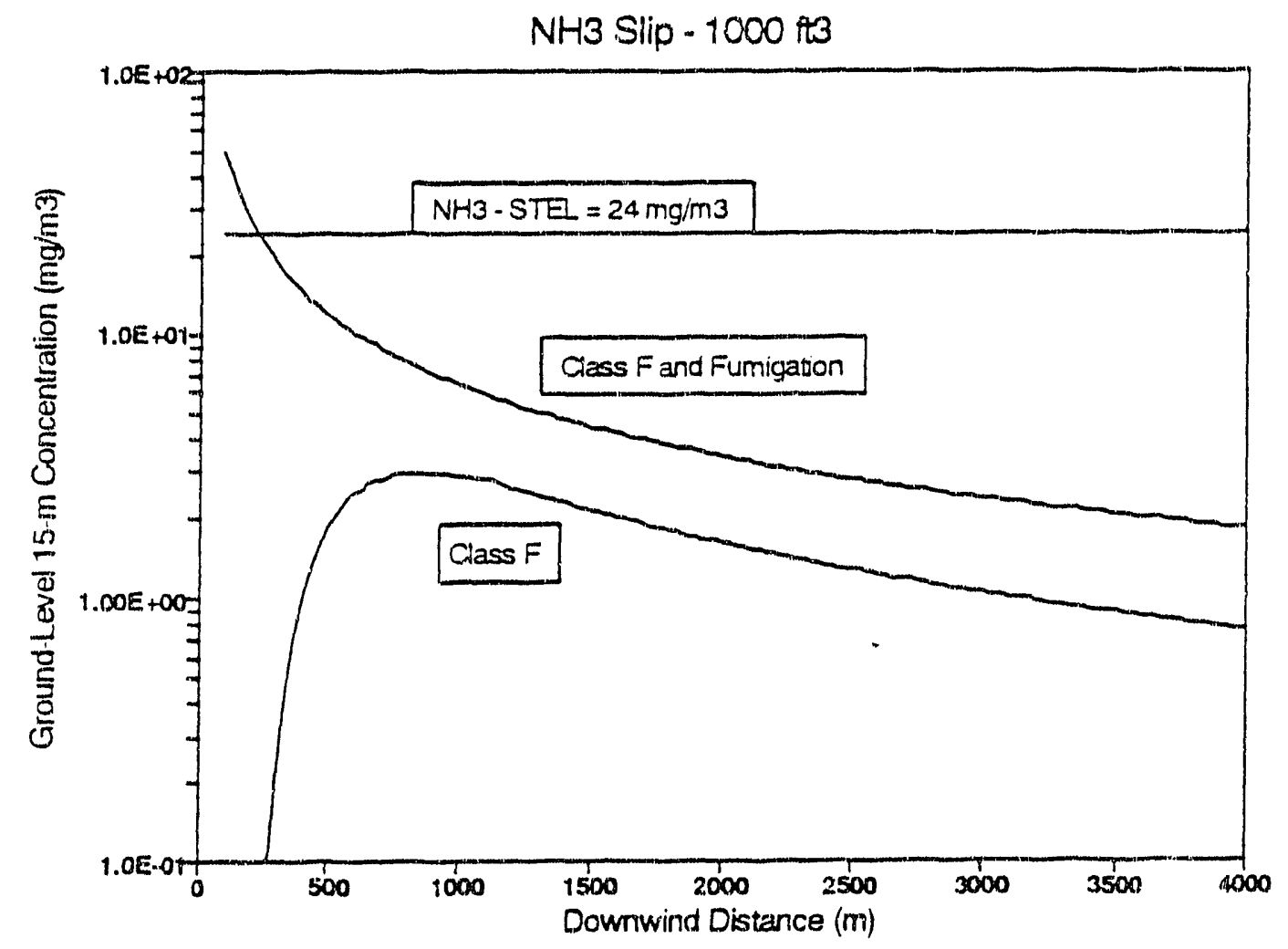

Figure 2. 15-min average $\mathrm{NH}_{3}$ concentrations at ground-level resulting from an $\mathrm{NH}_{3}$ slip and release of $1000 \mathrm{ft}^{3}$ of $\mathrm{NH}_{3}$ gas to the 18.3-m NAF stack. 
NO, Process Line Break. The maximum i5-min concentration at ground-level occurred under fumigation conditions and was calculated to be $36 \mathrm{mg} / \mathrm{m}^{3}$ (69 ppm) at $100-\mathrm{m}$ distance from the NAF stack. At $450 \mathrm{~m}$ from the stack, the concentration fell below the STEL limit $\left(9.6 \mathrm{mg} / \mathrm{rn}^{3}\right)$. The maximum concentration is below the ivel (100 ppm) that has been observed to cause serious health problems (pulmonary edema). Exposure to concentrations below 50 ppm may result in impaired pulmonary defense mechanisms.

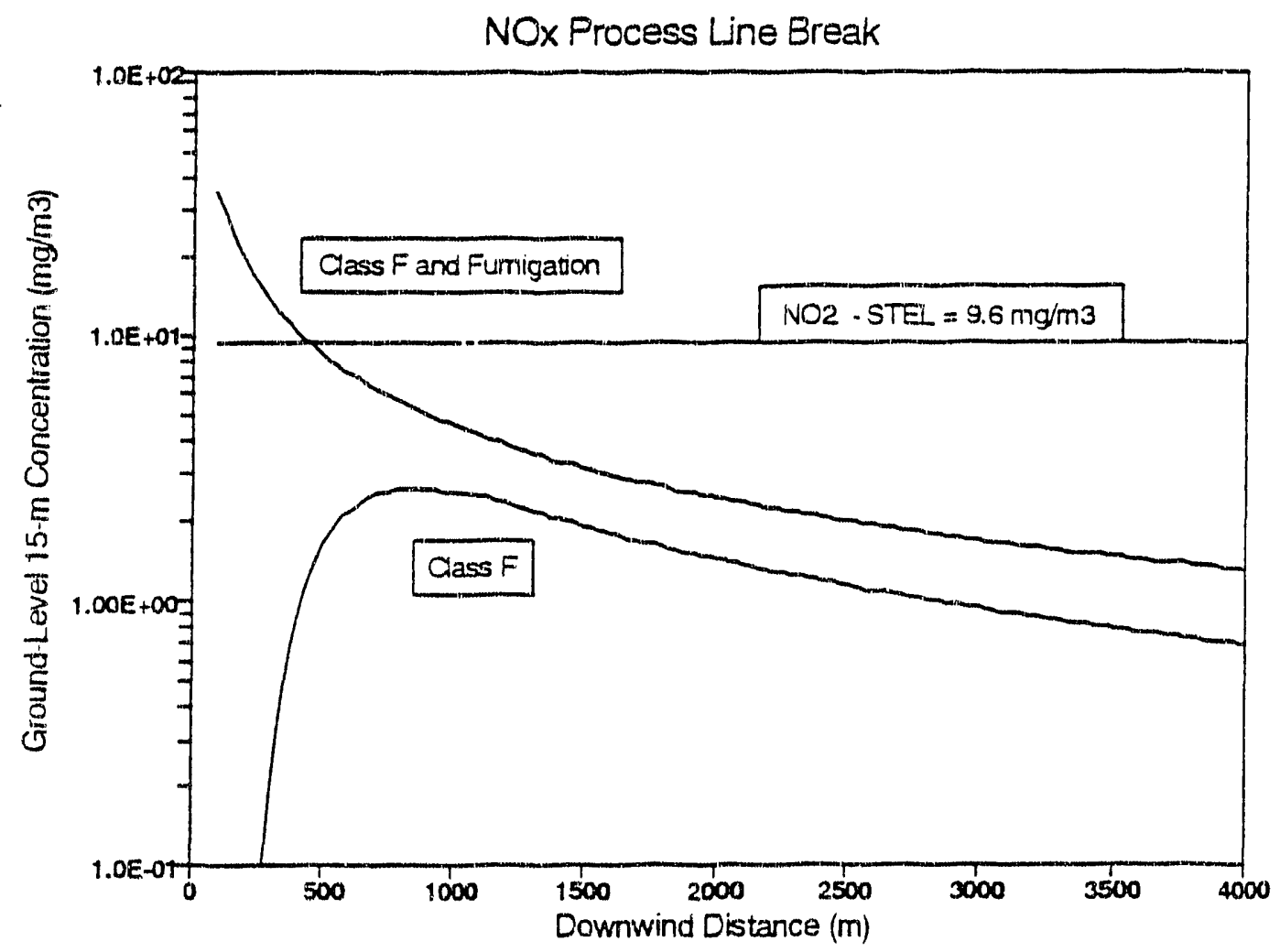

Figure 3. 15-min average $\mathrm{NO}_{2}$ concentrations at ground-level resulting from a $\mathrm{NO}_{\mathrm{x}}$ process line break and release of $\mathrm{NO}_{2}$ gas to the 18.3-m NAF stack. 
Storage Tank Relief Valve Malfunction. The maximum 15-min ground-level concentration was $3,400 \mathrm{mg} / \mathrm{m}^{3}$ and occurred at approximately $20-\mathrm{m}$ from the tank (Figure 4). At $100-\mathrm{m}$, the concentration was $1,000 \mathrm{mg} / \mathrm{m}^{3}$. The concentration decreased below the IDLH level at $300-\mathrm{m}$ distance and below the STEL level at 1.5 to $2 \mathrm{~km}$. Although concentrations from 1500 to $10,000 \mathrm{ppm}\left(1060\right.$ to $7080 \mathrm{mg} / \mathrm{m}^{3}$ ) may cause serious pulmonary health effects, the impacts from this release are not considered to be high risk due to the narrow width of the cloud $(17-\mathrm{m}$ effective half-width at $20-\mathrm{m})$. Individuals in the path of the plume would easily detect the pungent $\mathrm{NH}_{3}$ odor and could readily escape. The maximum concentration at the site boundary $\left(13.7 \mathrm{~km}\right.$ ) was $1 \mathrm{mg} / \mathrm{m}^{3}$ (Figure 5). 


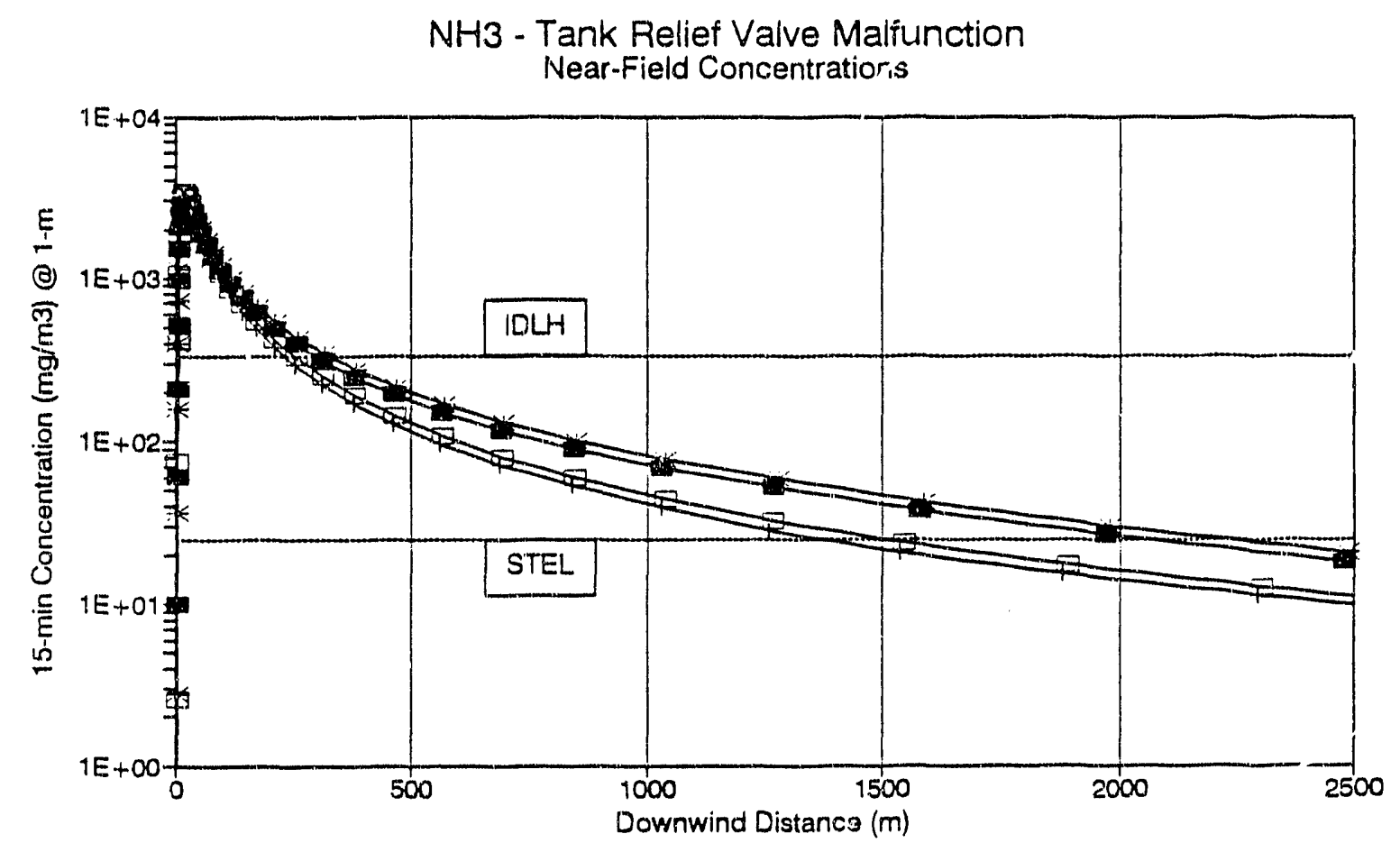

$-9 \mathrm{C}, 2 \mathrm{~m} / \mathrm{s}$ wind $+-90,4.2 \mathrm{~m} / \mathrm{s}$ wind $-20 \mathrm{C}, 2 \mathrm{~m} / \mathrm{s}$ wind $\leftrightarrows 20 \mathrm{C}, 4.2 \mathrm{~m} / \mathrm{s}$ wind

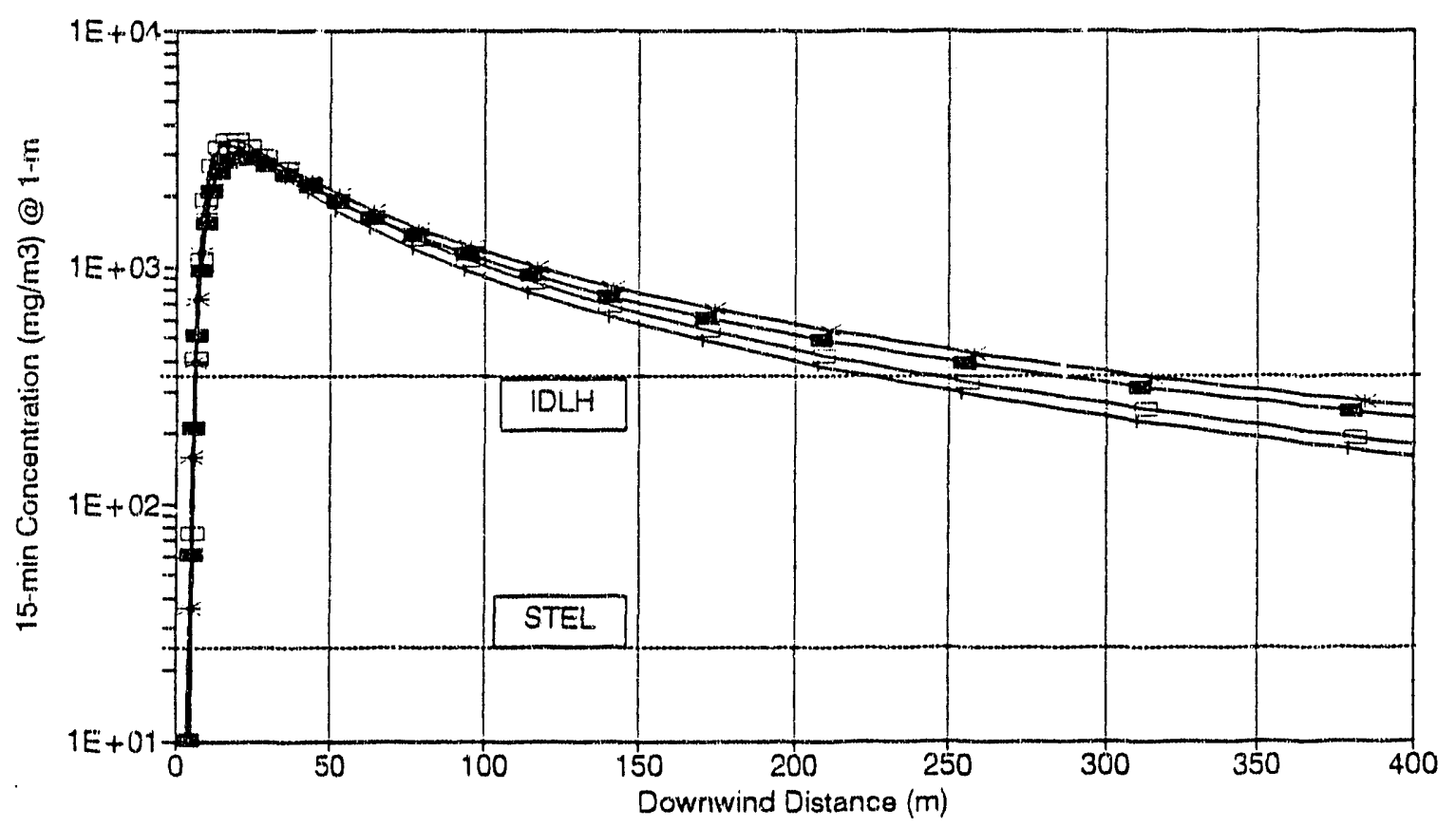

Figure 4. Near-field $\mathrm{NH}_{3}$ concentrations resulting from a tank relief valve malfunction. 


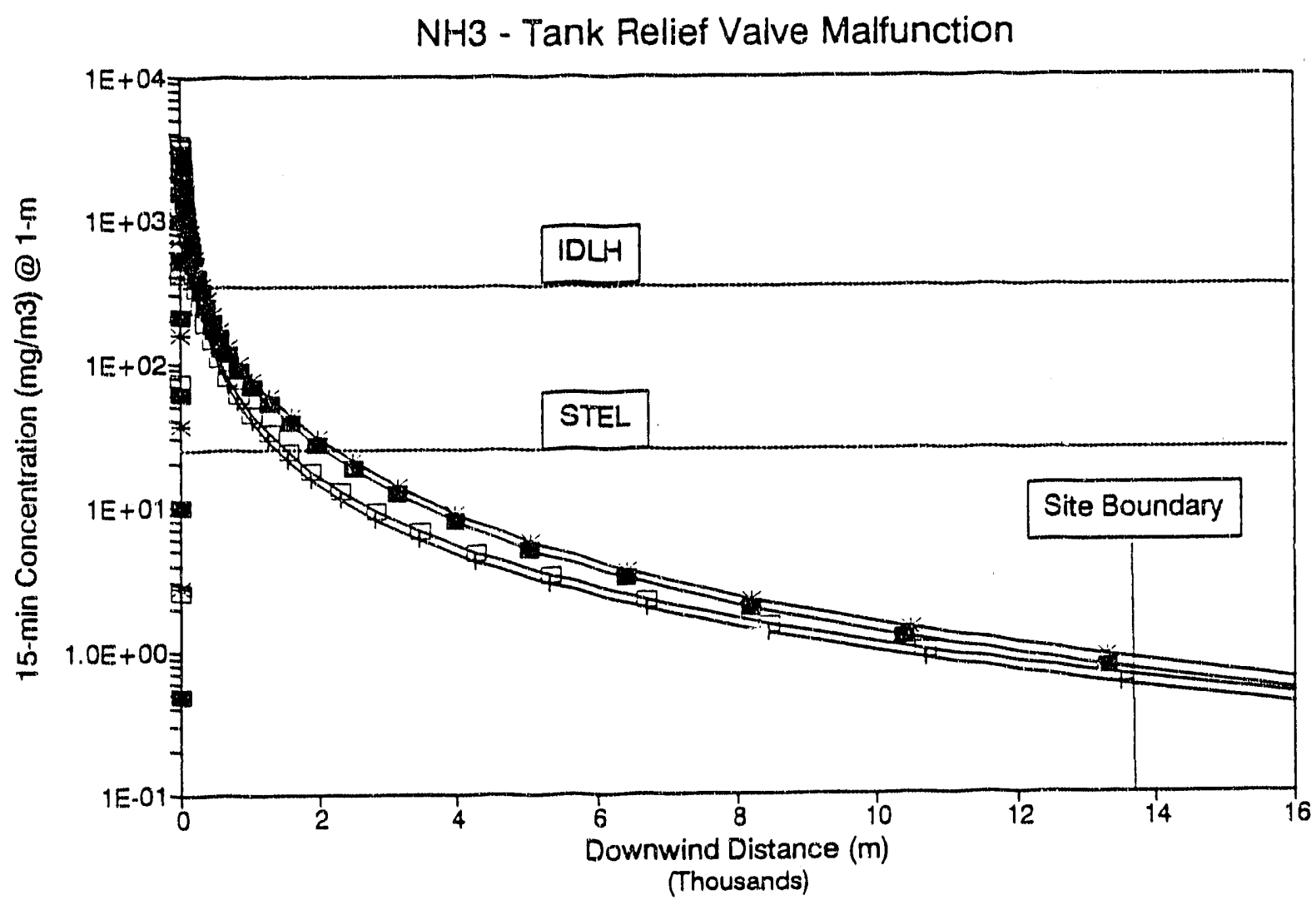

$-1.9 \mathrm{C}, 2 \mathrm{~m} / \mathrm{s}$ wind $--9 \mathrm{C}, 4.2 \mathrm{~m} / \mathrm{s}$ wind $\leftarrow 20 \mathrm{C}, 2 \mathrm{~m} / \mathrm{s}$ wind $\leftrightharpoons 20 \mathrm{C}, 4.2 \mathrm{~m} / \mathrm{s}$ wind

Figure 5. Maximum $15-\mathrm{min} \mathrm{NH}_{3}$ concentrations at the site boundary $(13.7 \mathrm{~km})$ resulting from a tank relief valve malfunction. 
Storage Tank Rupture. The maximum 15-min ground-level concentration was approximately $100,000 \mathrm{mg} / \mathrm{m}^{3}$ and occurred ai approximately $20-\mathrm{m}$ from the tank (Figure 6). At $100-\mathrm{m}$, the concentration was $50,000 \mathrm{mg} / \mathrm{m}^{3}$. The maximum concentration at the site boundary $\left(13.7 \mathrm{~km}\right.$ ) was $120 \mathrm{mg} / \mathrm{m}^{3}$ (Figure 7). The concentration decreased below the IDLH level at approximately $7 \mathrm{~km}$ and did not decrease below the STEL level for at least $18 \mathrm{~km}$ at wind speeds greater than $1 \mathrm{~m} / \mathrm{s}$. At a wind speed of $1 \mathrm{~m} / \mathrm{s}$, the aerosel cloud completely evapurated and lofted at approximately $10-\mathrm{km}$. Modeled concentratious be $y$ and $14 \mathrm{~km}$ are very uncertain and likely overestimated due to the high probability that meteorological conditions will change before the cloud reaches those distances.

Gaussian "pufi" model results for the same release mass and initial volume are also plotted in Figures 6 and 7. At close-in distances (less than 600-m), the puff model predictions are less than those calculated by SLAB. This is likely due to SLAB's ability to account for initial gravity slumping in the cold, dense $\mathrm{NH}_{3}$ cloud. At longer distances (Figure 7), the puff model concentrations are greater than those calculated by SLAB.

These results indicate that potentially serious health impacts may occur within 3-km downwind of this release (concentrations range from 1000 to $100,000 \mathrm{mg} / \mathrm{m}^{3}$ ). Health effects from short-term exposures of 1500 to $10,000 \mathrm{ppm}\left(1060\right.$ to $7080 \mathrm{mg} / \mathrm{m}^{3}$ ) include fatalities due to delayed pulmonary edema, bronchopneumonia, or asphyxiation due to spasms, inflammation, or edema of the larynx. Concentrations downwind that exceed $5000 \mathrm{ppm}$ $\left(3540 \mathrm{mg} / \mathrm{m}^{3}\right)$ (approximately $1.3 \mathrm{~km}$ ) may be rapidly fatal to those who are exposed to the cloud. ${ }^{13}$ 


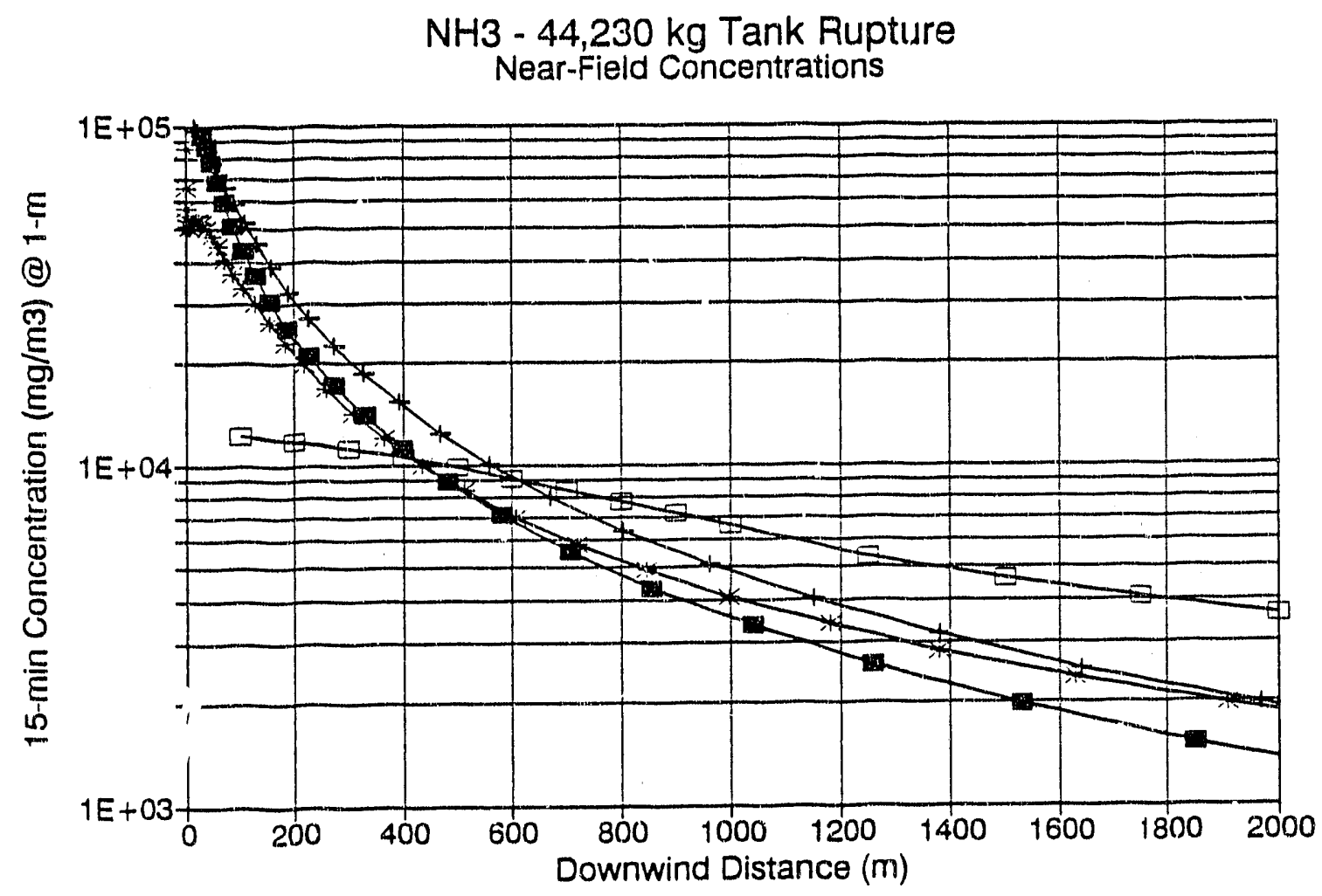

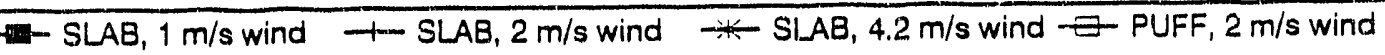

Figure 6. Near-field $\mathrm{NH}_{3}$ concentrations resulting from an 18,000 gallon storage tank rupture. 


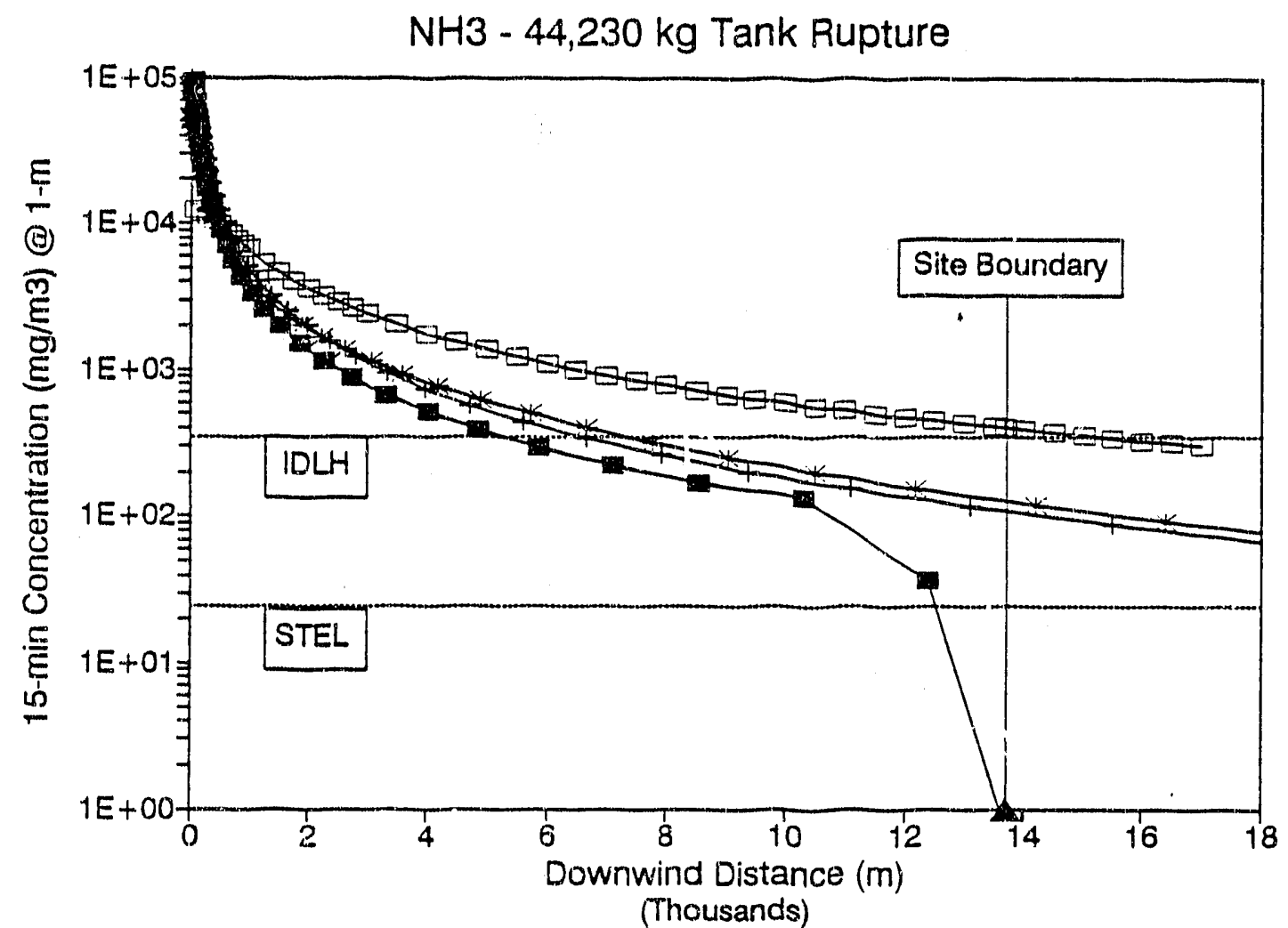

SLAB, $1 \mathrm{~m} / \mathrm{s}$ wind $\rightarrow$ SLAB, $2 \mathrm{~m} / \mathrm{s}$ wind $\%$ SLAB, $4.2 \mathrm{~m} / \mathrm{s}$ wind $\rightleftharpoons$ PUFF, $2 \mathrm{~m} / \mathrm{s}$ wind

Figure 7. Maximum 15-min $\mathrm{NH}_{3}$ concentrations at the site boundary $(13.7 \mathrm{~km})$ resulting from an 18,000 gallon storage tank rupture. 
Tanker Truck Accident. The maximum 15 -min ground-level concentration was approximately $25,000 \mathrm{mg} / \mathrm{m}^{3}$ immediately next to the release (Figure 8). At $100-\mathrm{m}$, the concentration was $15,000 \mathrm{mg} / \mathrm{m}^{3}$. The maximum concentration at the site boundary (13.7 $\mathrm{km}$, assuming the accident occurs at ICPP) was $50 \mathrm{mg} / \mathrm{m}^{3}$ (Figure 9). The concentration decreased below the IDLH level at approximately $4 \mathrm{~km}$ and did not decrease below the STEL level until approximately $18 \mathrm{~km}$. However, modeled concentrations beyond $14 \mathrm{~km}$ are very uncertain and likely overestimated due to the high probability that meteorological conditions will change before the cloud reaches those distances.

Gaussian "puff" model results for the same release mass and initial volume are also plotted in Figures 8 and 9. Again, the puff model predictions do not account for the sharp peak immediately next to the source and are higher than those predicted by SLAB at longer downwind distances.

These results indicate that potentially serious health impacts may occur within $1.5-\mathrm{km}$ downwind of this release (concentrations range from 1000 to $25,000 \mathrm{mg} / \mathrm{m}^{3}$ ). Concentrations downwind that exceed $5000 \mathrm{ppm}\left(3540 \mathrm{mg} / \mathrm{m}^{3}\right)$ (approximately $500 \mathrm{~m}$ ) may be rapidly fatal to those who are $x$ xposed to the cloud. 


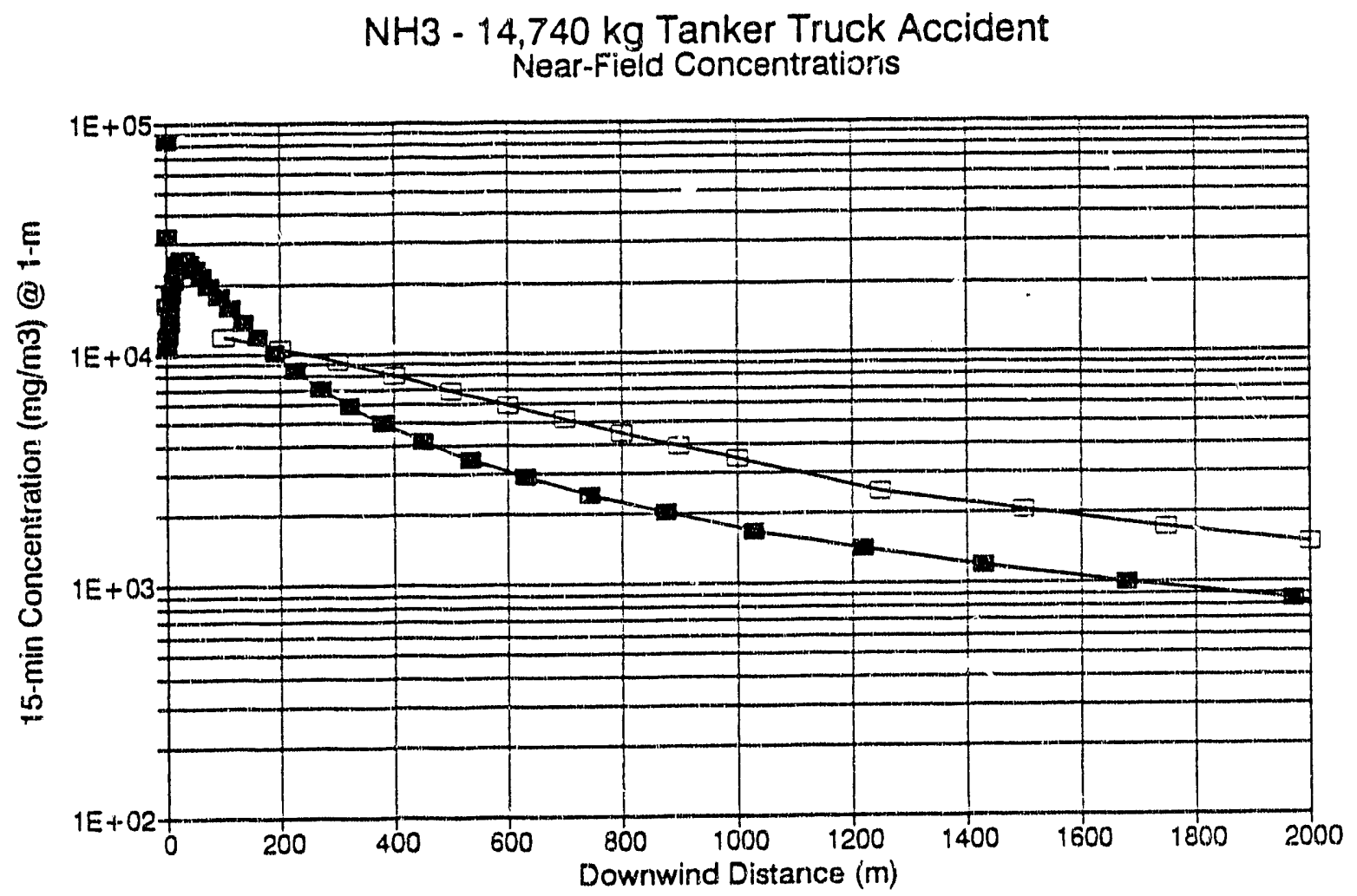

$S L A B, 2-4 \mathrm{~m} / \mathrm{s}$ wind $\square$ PUFF, $2 \mathrm{~m} / \mathrm{s}$ wind

Figure 8. Near-field $\mathrm{NH}_{3}$ concentrations resulting from a 6,000 gallon tanker truck accident. 


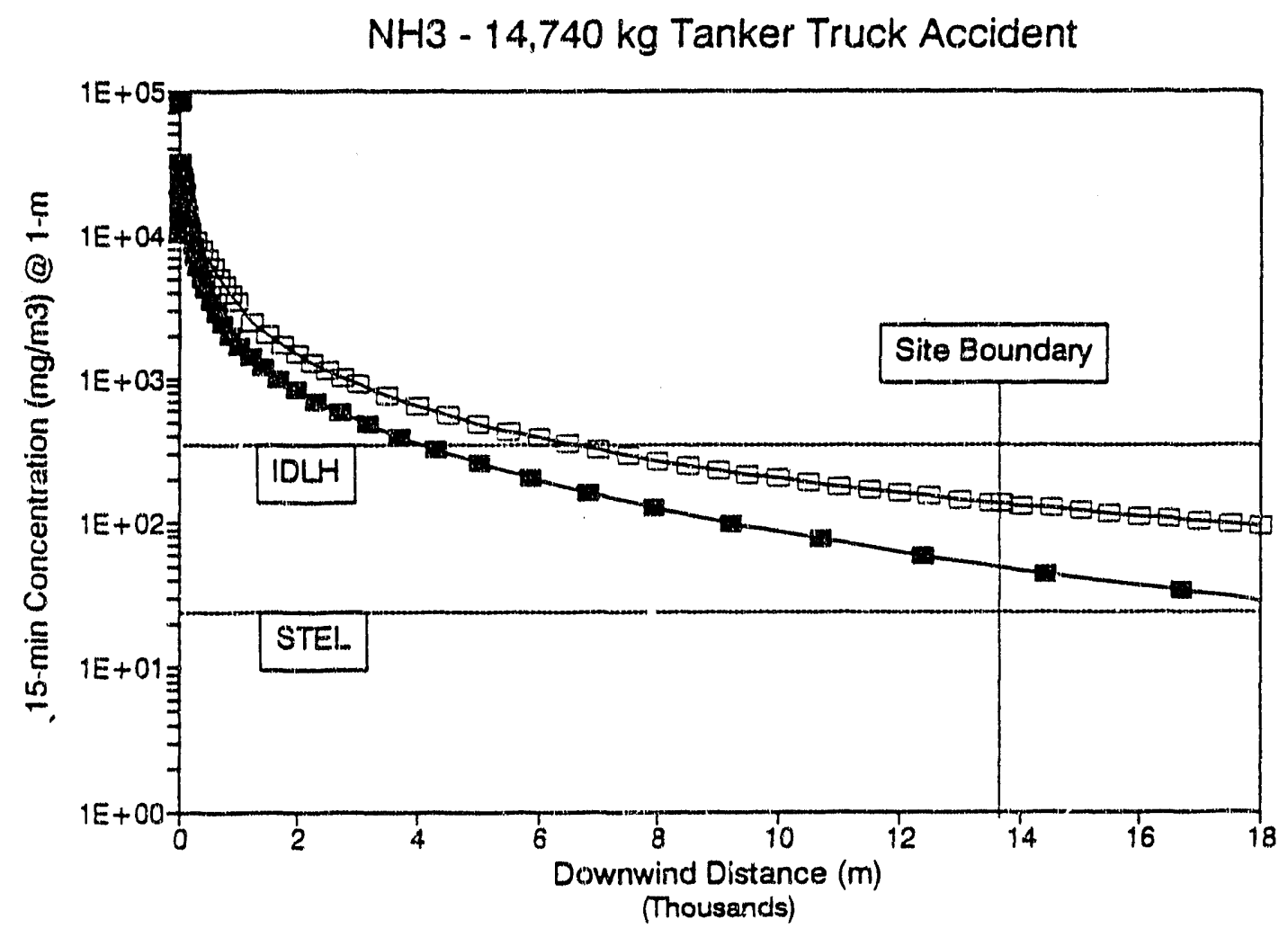

$-S L A B, 2-4 \mathrm{~m} / \mathrm{s}$ wind - PUFF, $2 \mathrm{~m} / \mathrm{s}$ wind

Figure 9. Maximum 15-min $\mathrm{NH}_{3}$ concentrations at the site boundary $(13.7 \mathrm{~km})$ resulting from a 6,000 gallon tanker truck accident. 


\subsection{REFERENCES}

1. Gifford, F. A., "An Outline of Theories of Diffusion in the Lower Layers of the Atmosphere", in D. H. Slade, ed. Meteorology and Atomic Energy, 1968, U.S. Department of Commerce, National Technical Information Service, Springfield, VA 22161.

2. Ermak, D. L., User's Manual for SLAB: An Atmospheric Dispersion Model for Denser-Than-Air Releases, University of California, Lawrence Livermore National Laboratory, Livermore, California, June 1990.

3. ACGIH, Threshold Limit Values for Chemical Substances and Physical Agents. American Conference of Government Industrial Hygienists, 1989.

4. P. D. Hendrickson (WINCO) letter to C. J. Schuetz, "Accident Scenarios for the Nox Abatement Plant," PDH-16-91, December 19, 1991.

5. C. J. Schuetz. (WINCO) letter to M. L. Abbott (EG\&G Idaho, Inc), "NO Abatement Accident Modeling Calculations," CJS-06-92, January 28, 1992.

6. National Institute for Occupational Safety and Health (NIOSH), Pocket Guide to Chemical Hazards, U.S. Department of Health and Human Services, Public Health Service, September 1985.

7. Federal Emergency Management Agency (FEMA), Handbook of Chemical Hazard Analysis Procedures, Publications Office, 500 C Street, S.W., Washington, D.C. 20472.

8. Kunkel, B. A., User's Guide for the Air Force Toxic Chemical Dispersion Model (AFTOX). Air Force Geophysical Laboratory, Hanscom AFB AFGL-TR-88-0009, 1988.

9. G. E. Start (NOAA) memorandum for Les Finch (WINCO), "Interim guidance for dispersion calculations at ICPP, March 24, 1989.

10. Clawson, K. L., G. E. Start, and N. R. Ricks, Climatography of the Idaho National Engineering Laboratory, 2nd Edition, DOE/ID-12118, December 1989, p. 124.

11. U.S. Nuclear Regulatory Agency, Regulatory Guide 1.145, "Atmospheric Dispersion Models for Potential Accident Consequence Assessments at Nuclear Power Plants", Revision 1, November 1982. 
12. Environmental Protection Agency (EPA), Guidance on the Application of Refined Dispersion Models for Air Toxics Releases, EPA-450/4-91-007, National Technical Information Service No. PB91-190983, March 1991.

13. Braker, W. and A. L. Mossman, Matheson Gas Data Book, Matheson--Division Searle Medical Products USA Inc, Lyndhurst, New Jersey, 1980.

14. Environmental Protection Agency (EPA), A Workbook of Screening Techniques for Assessing Impacts of Toxic Air Pollutants, EPA-450/4-88-009, National Technical Information Service No. PB89-134340, September 1988, p. 4-24.

15. Environmental Protection Agency (EPA), Guidelines On Air Quality Models (Revised), EPA-450/2-78-027R, July 1986, p. 9-23.

16. Occupational Health Services, Inc., Material Safety Data Sheet (MSDS) for ammonia and nitrogen dioxide, 450 Seventh Ave., Suite 2407, New York, NY 10123. 


\section{APPENDIX A}

\section{SLAB SENSITIVITY RUNS}


$\mathrm{NH} 3-44,230 \mathrm{~kg}$ INSTANTANEOUS

Minimum Monthly Temperature (Jan, $-9 \mathrm{C})$

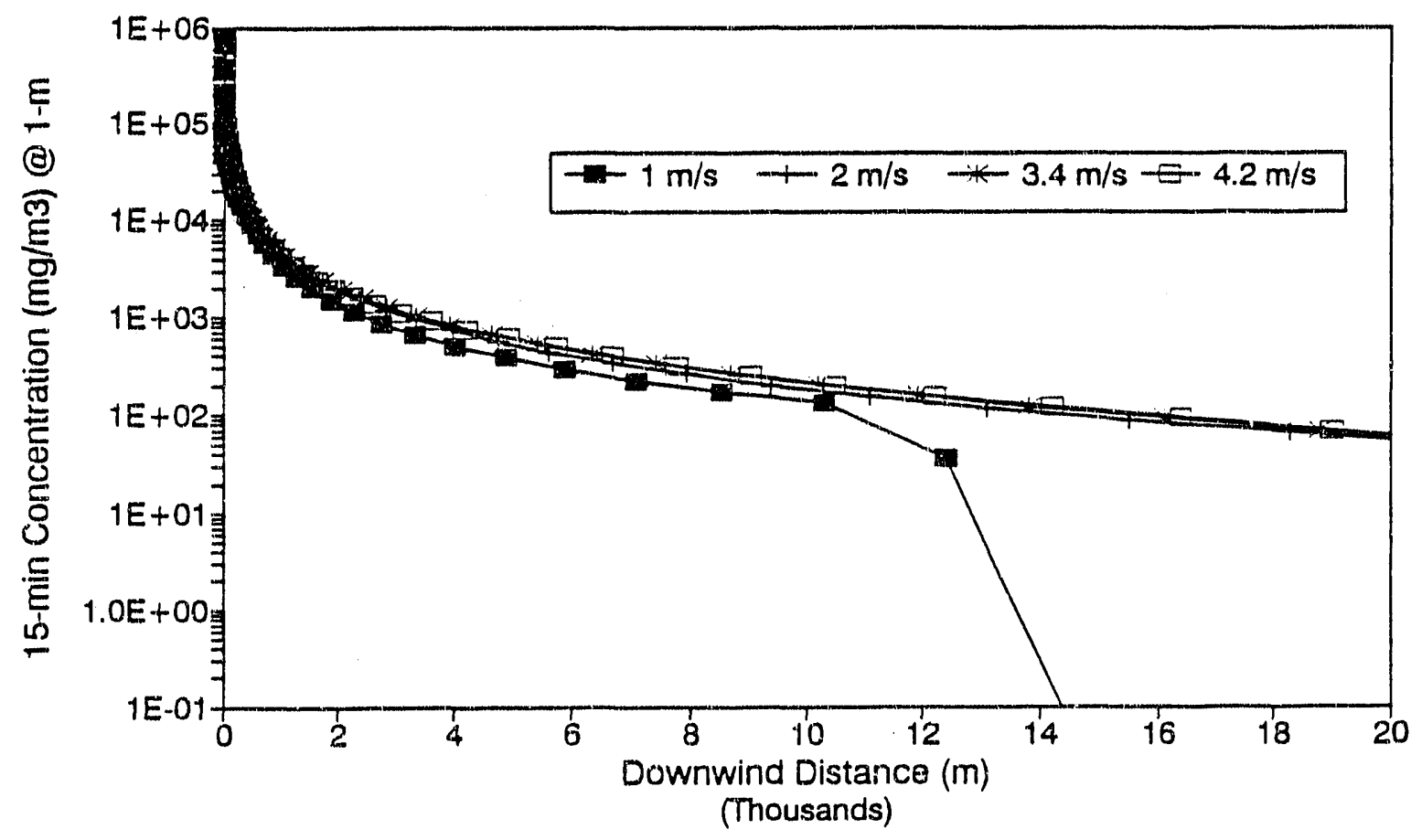

Figure A-1. SLAB maximum $15-\min \mathrm{NH}_{3}$ concentrations at ground-level for various wind speeds and an ambient temperature of $-9^{\circ} \mathrm{C}$ (lowest monthly average temperature at the INEL--January). 
$\mathrm{NH} 3-44,230 \mathrm{~kg}$ INSTANTANEOUS

Annual Average Temperature (5.6C)

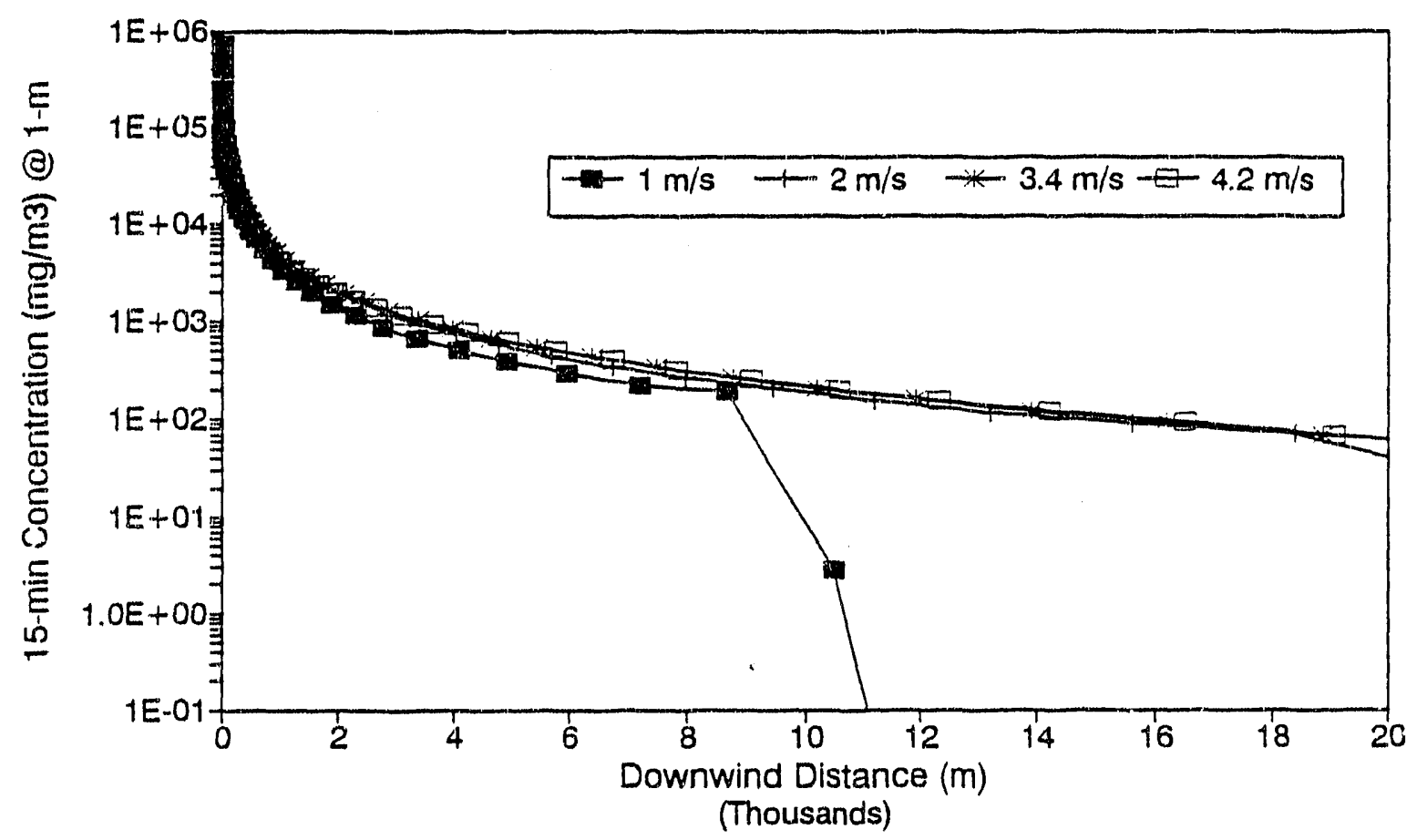

Figure A-2. SLAB maximum $15-\mathrm{min} \mathrm{NH}_{3}$ concentrations at ground-level for various wind speeds and an ambient temperature of $5.6^{\circ} \mathrm{C}$ (INEL annual average). 
$\mathrm{NH} 3-44,230 \mathrm{~kg}$ INSTANTANEOUS

Maximum Monthly Temperature (July, 20C)

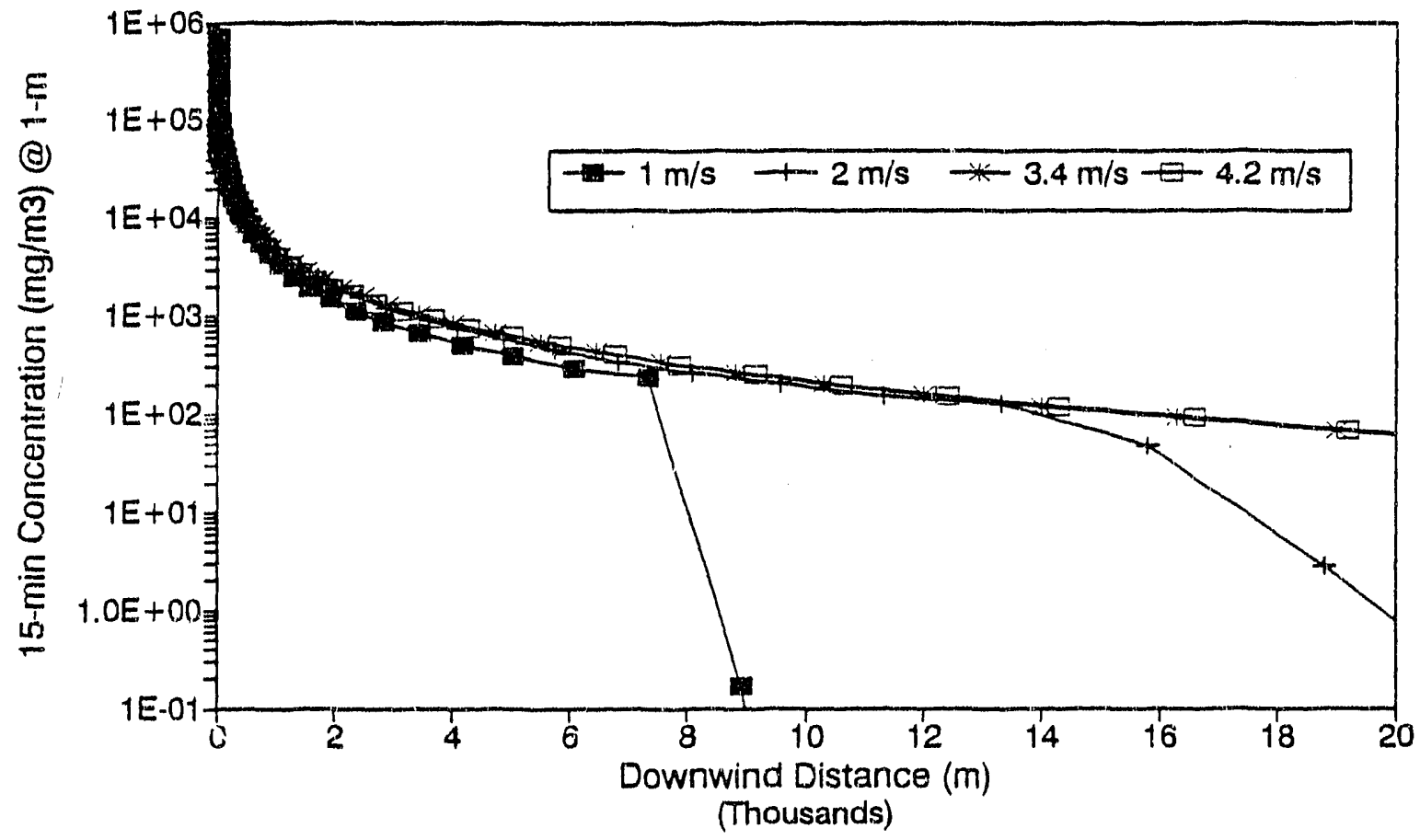

Figure A-3. $\mathrm{SLAB}$ maximum $15-\mathrm{min} \mathrm{NH}_{3}$ concentrations at ground-level for various wind speeds and an ambient temperature of $20^{\circ} \mathrm{C}$ (highest monthly average temperature at the INEL-.July). 


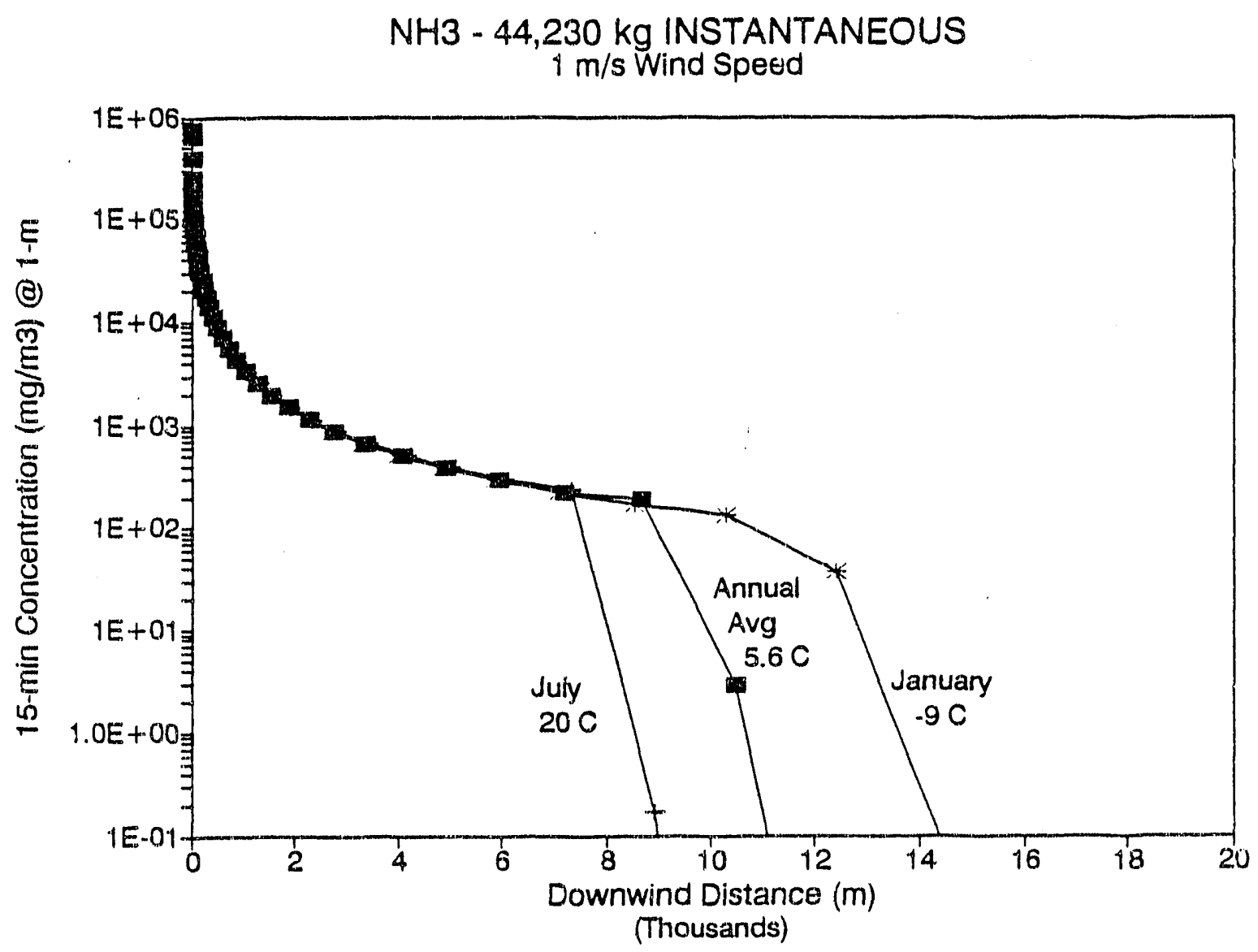

Figure A-4. SLAB maximum $15-\mathrm{min} \mathrm{NH}_{3}$ concentrations at ground-level for various monthly temperature averages at the INEL and at a wind speed of $1 \mathrm{~m} / \mathrm{s}$. 


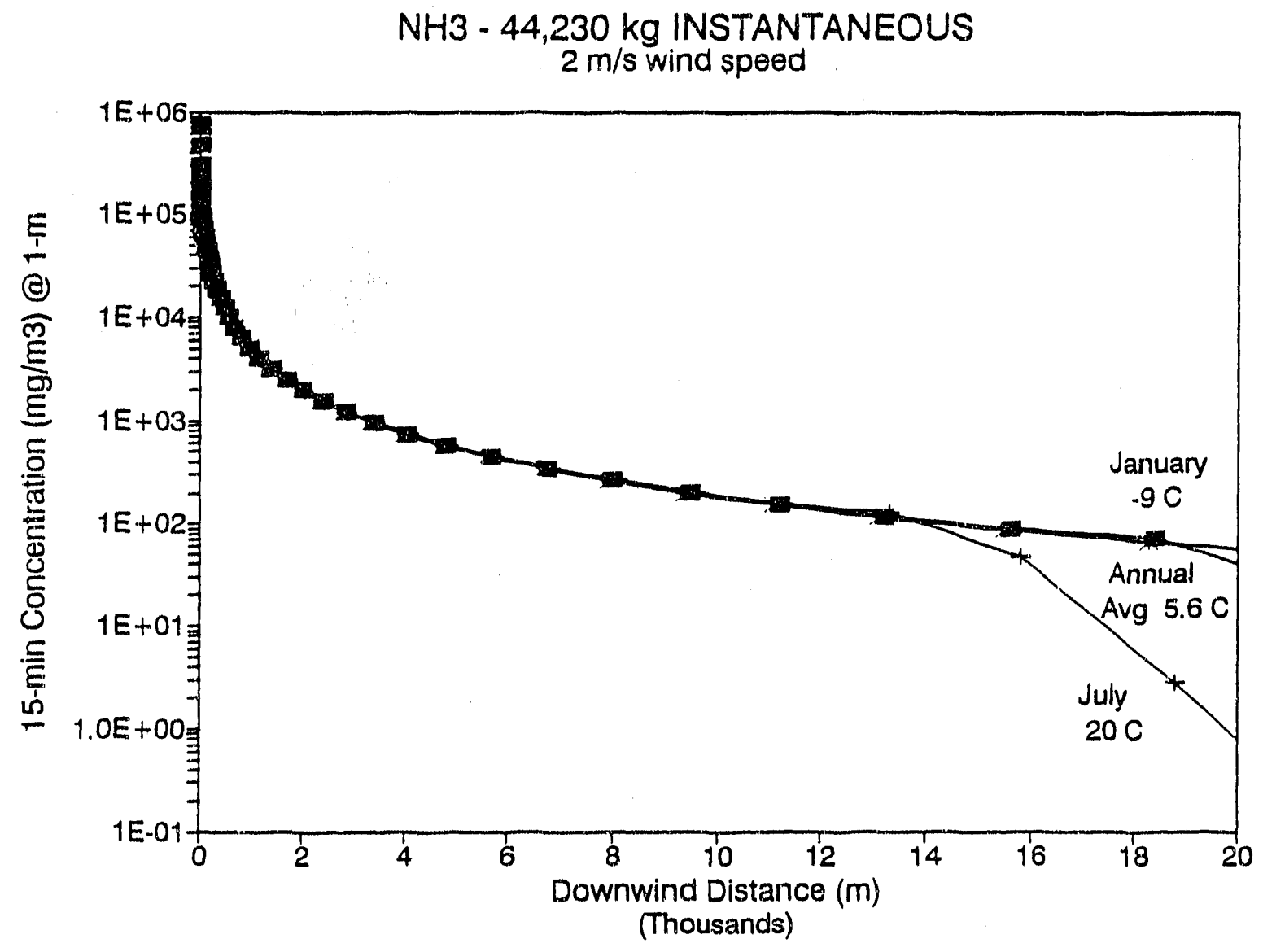

Figure A-5. SLAB maximum 15-min $\mathrm{NH}_{3}$ concentrations at ground-level for various monthly temperature averages at the INEL and at a wind speed of $2 \mathrm{~m} / \mathrm{s}$. 
$\mathrm{NH} 3-44,230 \mathrm{~kg}$ INSTANTANEOUS

$3.4 \mathrm{~m} / \mathrm{s}$ wind speed

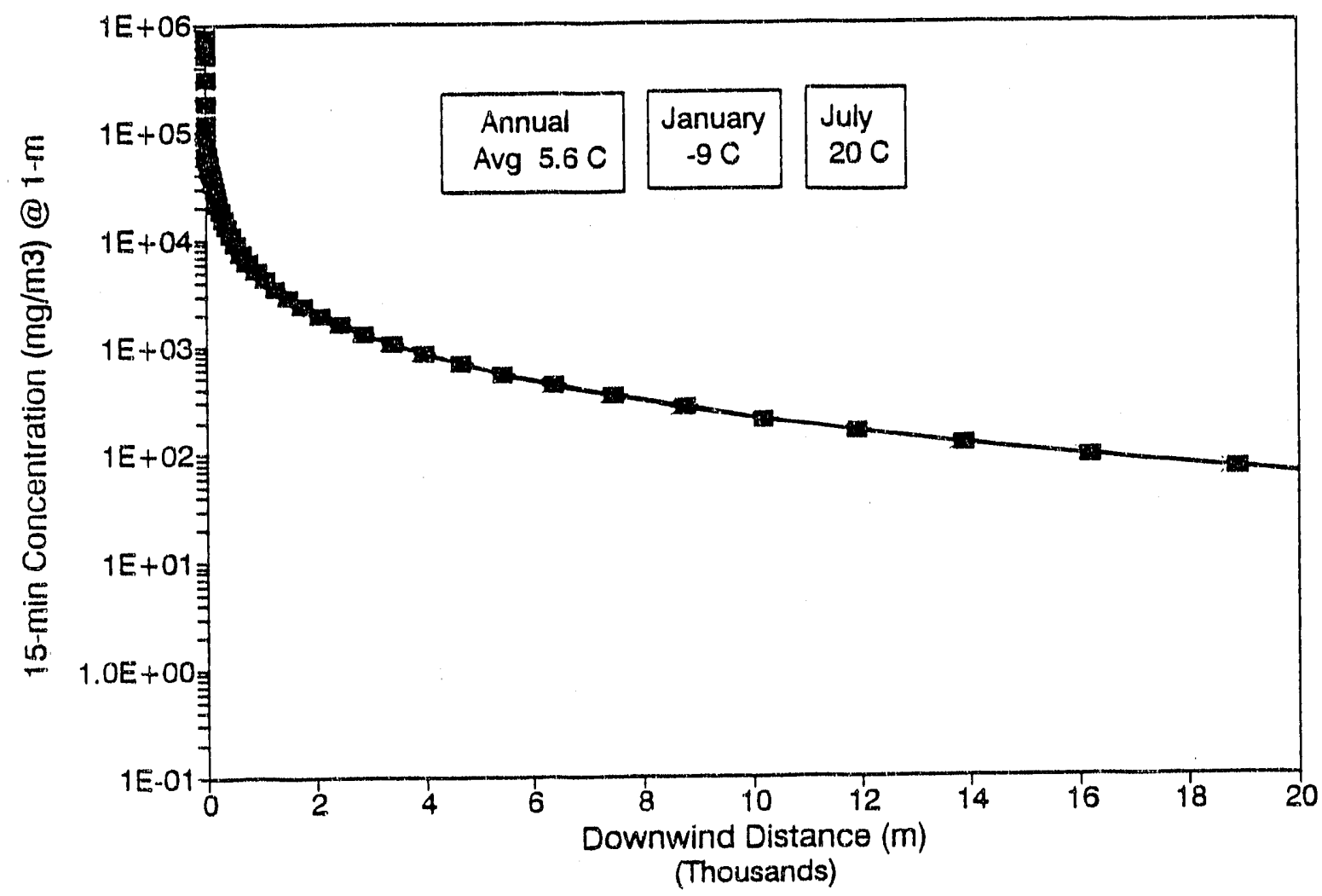

Figure A-6. SLAB maximum $15-\mathrm{min} \mathrm{NH}_{3}$ concentrations at ground-level for various monthly temperature averages at the INEL and at a wind speed of $3.4 \mathrm{~m} / \mathrm{s}$ (annual average for INEL). 


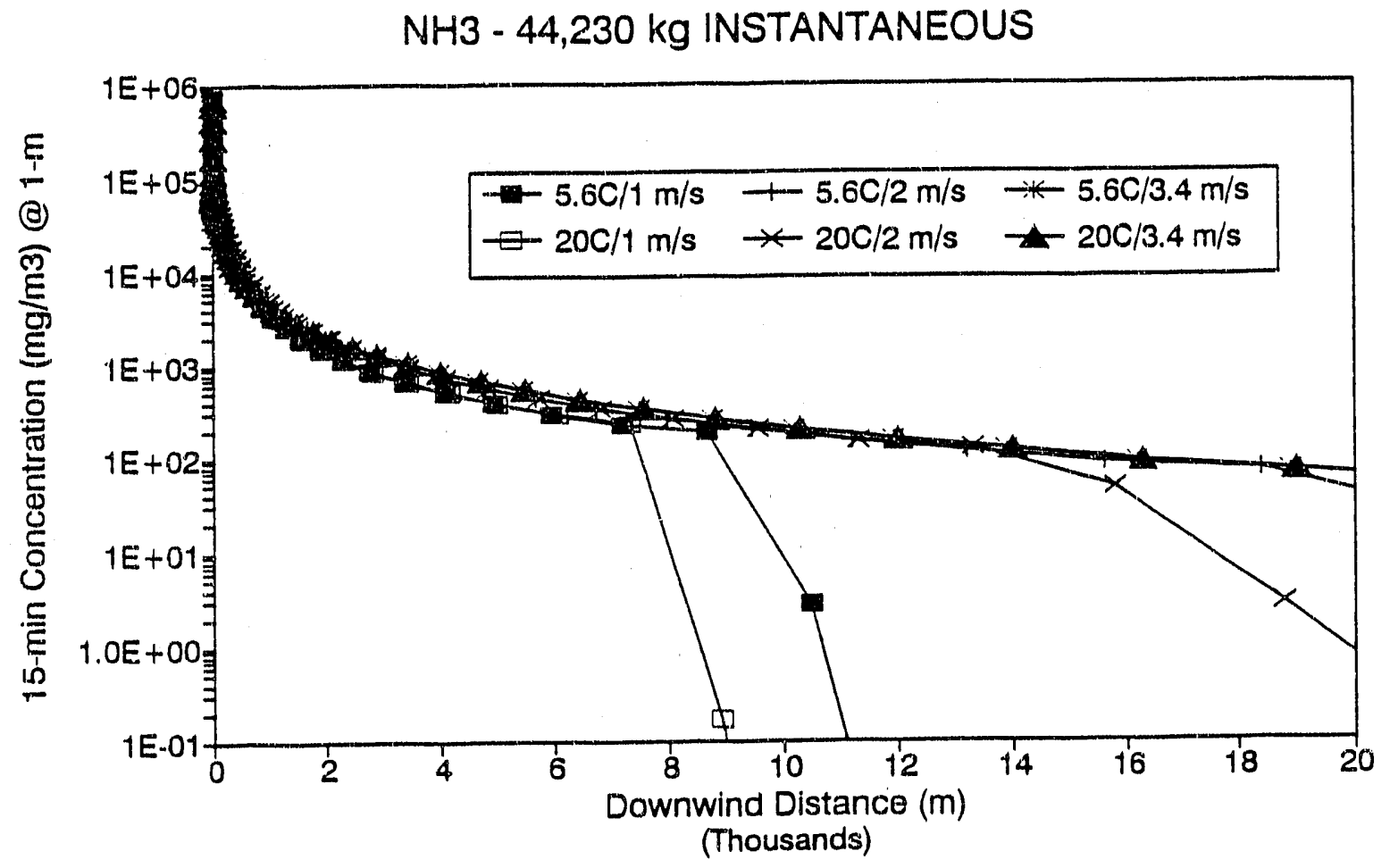

Figure A-7. SLAB maximum $15-\min \mathrm{NH}_{3}$ concentrations at ground-level for various monthly temperature averages at the INEL and various wind speeds. 

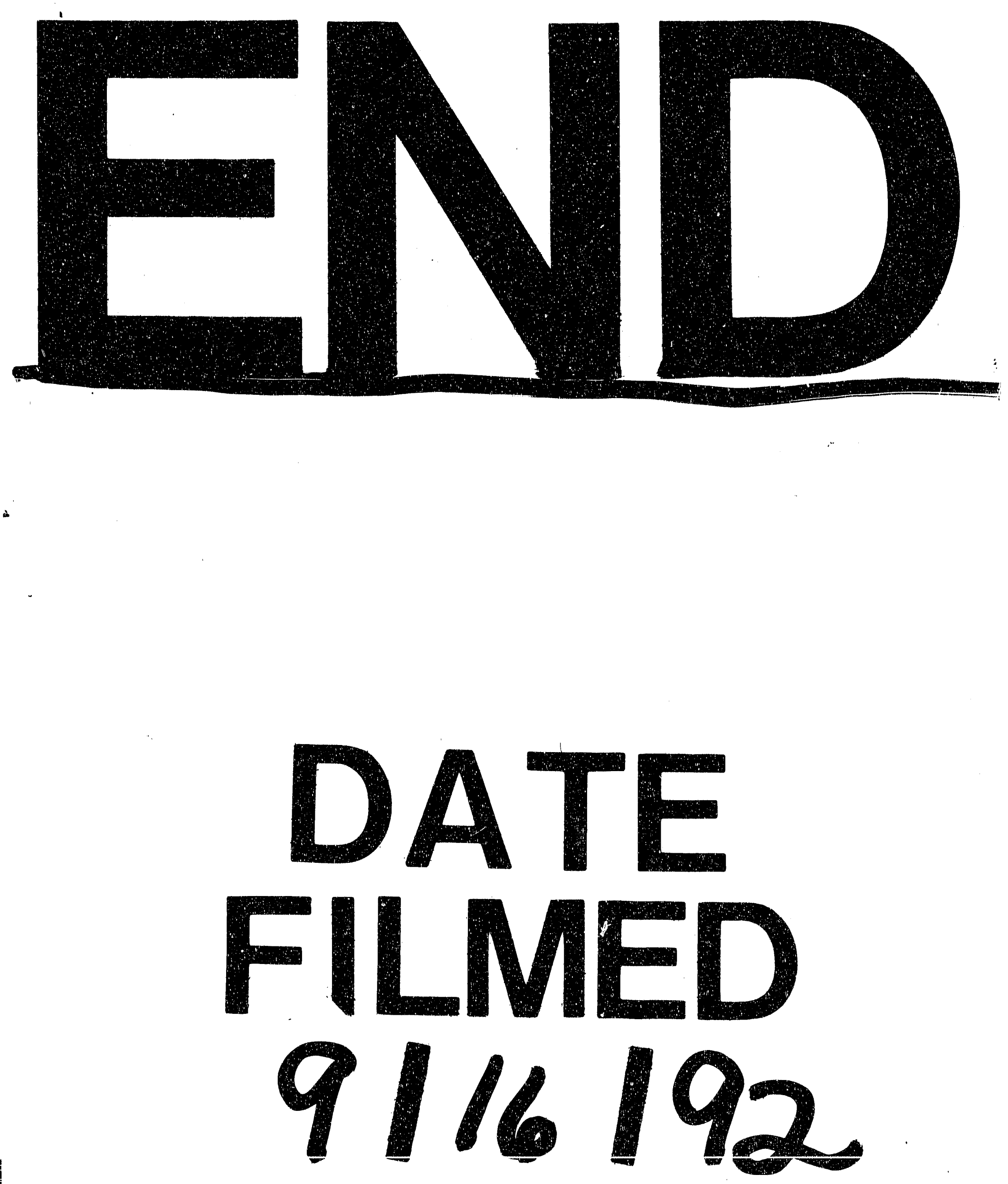

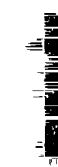

